\title{
Potential anticancer application of polyamine oxidation products formed by amine oxidase: a new therapeutic approach
}

\author{
E. Agostinelli $\cdot$ G. Tempera $\cdot$ N. Viceconte $\cdot$ \\ S. Saccoccio $\cdot$ V. Battaglia $\cdot$ S. Grancara $\cdot$ \\ A. Toninello $\cdot$ R. Stevanato
}

Received: 10 August 2009/Accepted: 20 October 2009/Published online: 10 December 2009

(C) Springer-Verlag 2009

\begin{abstract}
The polyamines spermine, spermidine and putrescine are ubiquitous cell components. These molecules are substrates of a class of enzymes that includes monoamine oxidases, diamine oxidases, polyamine oxidases and coppercontaining amine oxidases. Amine oxidases are important because they contribute to regulate levels of mono- and polyamines. In tumors, polyamines and amine oxidases are increased as compared to normal tissues. Cytotoxicity induced by bovine serum amine oxidase (BSAO) and spermine is attributed to $\mathrm{H}_{2} \mathrm{O}_{2}$ and aldehydes produced by the reaction. This study demonstrated that multidrugresistant (MDR) cancer cells (colon adenocarcinoma and melanoma) are significantly more sensitive than the corresponding wild-type (WT) ones to $\mathrm{H}_{2} \mathrm{O}_{2}$ and aldehydes, the products of BSAO-catalyzed oxidation of spermine. Transmission electron microscopy (TEM) observations showed major ultrastructural alterations of the mitochondria. These were more pronounced in MDR than in WT cells. Increasing the incubation temperature from 37 to $42^{\circ} \mathrm{C}$ enhances cytotoxicity in cells exposed to spermine metabolites. The combination $\mathrm{BSAO} /$ spermine prevents tumor growth, particularly well if the enzyme has been conjugated to a
\end{abstract}

E. Agostinelli $(\bowtie) \cdot$ G. Tempera $\cdot$ N. Viceconte $\cdot$ S. Saccoccio Department of Biochemical Sciences - SAPIENZA University of Rome and CNR, Biology and Molecular Pathology Institutes, Piazzale Aldo Moro 5, 00185 Rome, Italy

e-mail: enzo.agostinelli@uniroma1.it

V. Battaglia $\cdot$ S. Grancara $\cdot$ A. Toninello

Department of Biological Chemistry, University of Padua,

35121 Padua, Italy

R. Stevanato

Department of Physical Chemistry,

University of Venice "Ca' Foscari",

Dorsoduro 2137, 30123 Venice, Italy biocompatible hydrogel polymers. Since both wild-type and MDR cancer cells after pre-treatment with MDL 72527, a lysosomotropic compound, are sensitized to subsequent exposure to $\mathrm{BSAO} /$ spermine, it is conceivable that combined treatment with a lysosomotropic compound and BSAO/ spermine would be effective against tumor cells. It is of interest to search for such novel compounds, which might be promising for application in a therapeutic setting.

Keywords Polyamine - Amine oxidases - Tumor cells · Multidrug resistance $\cdot$ Hyperthermia

$\begin{array}{ll}\text { Abbreviations } & \\ \text { ADR } & \text { Adriamycin-resistant cells } \\ \text { ALDH } & \text { Aldehyde dehydrogenase } \\ \text { AO } & \text { Amine oxidase } \\ \text { APAO } & N^{1} \text {-Acetylpolyamine oxidase } \\ \text { BSAO } & \text { Bovine serum amine oxidase } \\ \text { CHO } & \text { Chinese hamster ovary } \\ \text { CuAO } & \text { Copper amine oxidase } \\ \text { Cu/TPQ-AO } & \text { Amine oxygen oxidoreductase copper- } \\ & \text { containing } \\ \text { DAO } & \text { Diamine oxidase } \\ \text { DFMO } & \text { Difluoromethylornithine } \\ \text { DX } & \text { Doxorubicin-resistant cells } \\ \text { FAD } & \text { Flavin adenine dinucleotide } \\ \text { hVAP-1 } & \text { Human vascular adhesion protein-1 } \\ \text { LoVo } & \text { Colon adenocarcinoma cell } \\ \text { LOX } & \text { Lysyl oxidase } \\ \text { M14 } & \text { Melanoma cell } \\ \text { MAO } & \text { Monoamine oxidase } \\ \text { MDL 72527 } & N^{1}, N^{4} \text {-bis(2,3-butadienyl)-1,4- } \\ \text { MDR } & \text { butanediamine } \\ & \text { Multidrug-resistant }\end{array}$




$\begin{array}{ll}\text { NSAIDS } & \text { Non-steroidal anti-inflammatory drugs } \\ \text { PAO } & \text { Polyamine oxidase } \\ \text { PEG } & \text { Polyethylene glycol } \\ \text { P-gp } & \text { P-glycoprotein } \\ \text { ROS } & \text { Reactive oxygen species } \\ \text { SAO } & \text { Serum amine oxidase } \\ \text { SH } & \text { Thiol groups } \\ \text { SMO } & \text { Spermine oxidase } \\ \text { SSAO } & \text { Semicarbazide-sensitive amine oxidase } \\ \text { TEM } & \text { Transmission electron microscopy } \\ \text { LTQ } & \text { Lysine tyrosylquinone } \\ \text { TNF } \alpha & \text { Tumor-necrosis factor } \alpha \\ \text { TPQ } & \text { 2,4,5-Trihydroxyphenylalaninequinone } \\ \text { VAP-1 } & \text { Vascular adhesion protein-1 } \\ \text { WR 1065 } & \text { Aminothiol } N \text {-(2-mercaptoethyl)- } \\ & 1,3 \text {-propanediamine } \\ \text { WT } & \text { Wild-type }\end{array}$

\section{Introduction}

The polyamines spermine, spermidine and putrescine are ubiquitous cell components, which are essential for cell proliferation and differentiation (Pegg 1988). They attract interest because of their multiple functions in cell biology (Cohen 1998) including, among many others, cell cycle regulation, gene expression and signal transduction (Bachrach et al. 2001; Childs et al. 2003). Moreover, it has been demonstrated that intracellular accumulation of polyamines can induce programmed cell death (or apoptosis) in various cell types (Tobias and Kahana 1995) through activation of the caspase cascade (Stefanelli et al. 1998, 1999). The activation of caspases is triggered by the release of mitochondrial cytochrome $c$ (Ghafourifar et al. 1999; Andreyev and Fiskum 1999; Hengartner 2000), which has been shown to be induced by spermine or spermidine (Stefanelli et al. 2000). The natural polyamines are substrates of several flavin adenine dinucleotide (FAD)dependent enzymes [monoamine oxidase (MAO), polyamine oxidase (PAO), spermine oxidase (SMO)] and of copper amine oxidases (CuAOs) [diamine oxidase (DAO), serum amine oxidases (SAO), lysyl oxidase (LOX)] (Arancia et al. 2004; Agostinelli et al. 2004). Two isoforms, termed monoamine oxidases $\mathrm{A}$ and $\mathrm{B}$, are present in approximately the same amounts in the outer mitochondrial membrane (Edmondson et al. 2009; La Regina et al. 2007) and inhibition of either of them has been demonstrated to protect cells against apoptosis (Malorni et al. 1998; Paterson and Tatton 1998). PAO is involved in the homeostatic regulation of polyamine pools. The other oxidases are important for the terminal catabolism of polyamines, i.e., they catalyze the formation of metabolites (ammonia and amino acids) that can be excreted via the kidneys (Seiler 1992). Products of polyamine oxidation are toxic to cells. In serum-containing cell cultures, cytotoxicity of polyamines correlates with their property as substrates of serum amine oxidases (Morgan 1988). Oxidation represents a crucial reaction in polyamine metabolism, by means of which these polycations enter the catabolic routes for irreversible inactivation and elimination. Mono-, di- and polyamines, as well as several $N$-acyl amines, are oxidatively deaminated by amine oxidases (AOs) in a reaction consuming $\mathrm{O}_{2}$ and $\mathrm{H}_{2} \mathrm{O}$, either by the removal of one primary amino group or by the cleavage of the molecule at the secondary nitrogen atoms and oxidation of the terminal carbon of the remaining molecule to an aldehyde group during the same catalytic cycle. Oxidative deamination produces aldehyde, amine and $\mathrm{H}_{2} \mathrm{O}_{2}$ in stoichiometric amounts according to the following equations (Bellelli et al. 2000; Agostinelli et al. 2009a; Edmondson et al. 2007, 2009):

1. $\mathrm{R}-\mathrm{CH}_{2}-\mathrm{NH}_{2}+\mathrm{H}_{2} \mathrm{O}+\mathrm{O}_{2} \rightarrow \mathrm{R}-\mathrm{CHO}+\mathrm{NH}_{3}+$ $\mathrm{H}_{2} \mathrm{O}_{2}$

2. $\mathrm{R}-\mathrm{CH}_{2}-\mathrm{NH}-\mathrm{CH}_{2}-\mathrm{R}+\mathrm{H}_{2} \mathrm{O}+\mathrm{O}_{2} \rightarrow \mathrm{R}-\mathrm{CHO}+$ $\mathrm{NH}_{2}-\mathrm{CH}_{2}-\mathrm{R}+\mathrm{H}_{2} \mathrm{O}_{2}$

1. Cleavage at the primary amino group (operated by both copper and FAD-dependent AOs).

2. Cleavage at the secondary amino group (operated by the FAD-dependent AOs).

This minireview deals with the fundamental structural properties of a $\mathrm{Cu} / \mathrm{TPQ}$ (copper/2,4,5-trihydroxyphenylalaninequinone) $\mathrm{AO}$ isolated from bovine serum (BSAO) (Turini et al. 1982), involving the formation of a Schiff base between the amine substrate and the organic cofactor (Bellelli et al. 2000; Agostinelli et al. 2009a). Moreover, it describes the possibility of using purified $\mathrm{BSAO}$, in the presence of exogenous spermine or endogenous polyamines, to induce cytotoxicity, on several human tumor cell lines in vitro (Calcabrini et al. 2002; Agostinelli et al. 2009b) or after injection of the enzyme into the tumor in vivo (Averill-Bates et al. 2005). Amine oxidases metabolize preferentially polyamines (spermine and spermidine) to generate the reaction products $\mathrm{H}_{2} \mathrm{O}_{2}$ and aldehyde(s) (Fig. 1) (Agostinelli and Seiler 2006). Such toxic products are able to induce stress-activated signal transduction pathways, leading to cell death, by necrosis or apoptosis (Lindsay and Wallace 1999; Seiler and Raul 2005; Agostinelli et al. 2006a).

The research for innovative therapeutic approaches, based on the use of new pharmacological agents or drug associations effective against resistant tumors and, possibly, with a low degree of undesirable side effects, is gaining interest in clinical oncology. In our study carried 


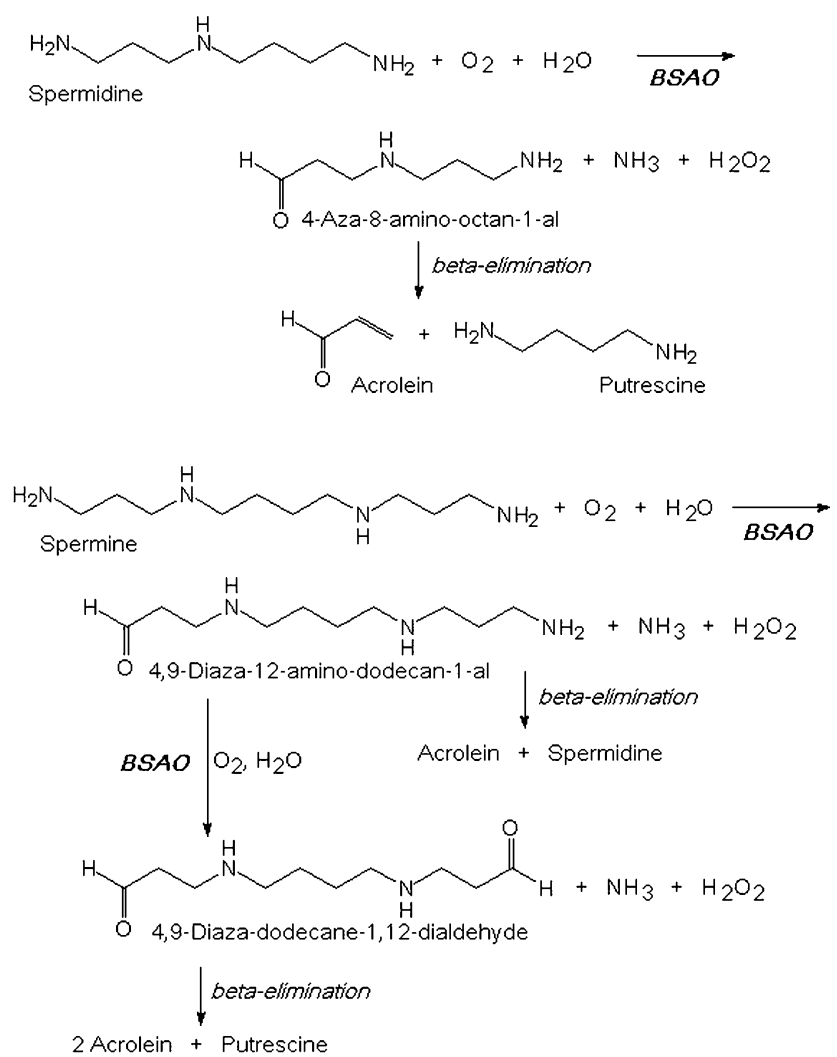

Fig. 1 Reaction scheme of the oxidative deamination of spermidine and spermine by bovine serum amine oxidase

out on melanoma (M14) (Agostinelli et al. 2006a) and colon adenocarcinoma (LoVo) (Agostinelli et al. 2006b) human cancer cells, it was observed that $\mathrm{H}_{2} \mathrm{O}_{2}$ and aldehydes, generated by subcytotoxic concentrations of BSAO and spermine, exerted higher cytotoxic effect on doxorubicin-resistant cells (M14 ADR and LoVo DX) than on their parental sensitive counterparts (M14 WT and LoVo WT). The findings showed that (a) multidrug-resistant (MDR) cells are more sensitive than wild-type cells to the cytotoxic effect of the enzymatic oxidation products of spermine, (b) cytotoxicity was mainly due to the presence of $\mathrm{H}_{2} \mathrm{O}_{2}$ and completely inhibited in the presence of both catalase and NAD-dependent aldehyde dehydrogenase (ALDH), (c) mitochondria seem to play a pivotal role in determining the differential response between sensitive and drug-resistant cells.

\section{Classification and occurrence of amine oxidases in living organisms}

The superfamily of AOs represents an important class of enzymes present in numerous living systems. These enzymes differ with respect to their molecular architecture, catalytic mechanisms, patterns of substrate specificity and inhibitor sensitivity, and subcellular localizations (Agostinelli et al. 2004). In the most common classification, these enzymes (amine: oxygen oxidoreductases, AOs, E.C. 1.4.3.4.) are divided into two classes, based on the chemical nature of the cofactors involved (Mondovì et al. 1989). The first class is characterized by the presence of FADAOs, ubiquitous enzymes in the cells of most mammalian species, and the PAOs found principally in vertebrates and plants (Binda et al. 2002). The second class consists of enzymes having a tightly bound $\mathrm{Cu}^{2+}$ ion and a carbonyltype group identified as either a 6-hydroxydopa quinone (2,4,5-trihydroxyphenylalaninequinone, TPQ) or a lysine tyrosylquinone (LTQ) at their active site. TPQ is easily detected, thanks to its pink absorption and its reactivity toward semicarbazide and phenylhydrazine; however, its chemical identification is relatively recent (Janes et al. 1990). Both FAD- and $\mathrm{Cu}^{2+} / \mathrm{TPQ}$-amine oxidases have been isolated and characterized from numerous organisms ranging from microorganisms, plants and mammals. FADAOs are mainly intracellular enzymes, often associated with the outer mitochondrial membrane (Edmondson et al. 2007, 2009), whereas CuAOs are either intra- or extracellular enzymatic proteins, or in some cases integral plasma membrane proteins (Agostinelli et al. 2007a, 2009a; Floris and Mondovì 2009) (Table 1).

Mitochondrial monoamine oxidases are primarily involved in the metabolism of the biogenic monoamine neurotransmitters and exogenous aryl-alkylamines. They therefore play a role of secondary importance in the oxidation of acetylated polyamines. In mammals, two different forms of MAOs are present in most tissues, namely MAO-A and MAO-B (Abell and Kwan 2001), classified on the basis of their selective inhibition by clorgyline and selegiline (L-deprenyl), respectively (Binda et al. 2007; La Regina et al. 2007). Isoenzyme A occurs in catecholaminergic neurons, while isoenzyme B is present in neurons and glial cells of the human brain and also in other different cell types. This different localization suggests that the two isoforms have different physiological functions. In fact, A and B MAOs are probably related to psychiatric and neurological disorders such as depression and Parkinson's disease, respectively (Checkoway et al. 1998; Mallajosyula et al. 2008). Bianchi et al. (2005) suggested the involvement of MAO-A in cardiac cellular degeneration, since MAO-A levels have been found to dramatically increase in the heart of aged rats. The consequence of this increase in the level of MAO-A in the heart is suggested to involve increased apoptosis and necrosis of cardiac cells due to increased levels of ROS from the $\mathrm{H}_{2} \mathrm{O}_{2}$ produced. Among other roles, in humans both amine oxidases, MAO-A and MAO-B, are the major enzyme systems involved in vivo in the oxidative metabolism of xenobiotic amines, drugs, in particular (Strolin Benedetti et al. 2007). 
Table 1 Classification and major characteristics of the amine oxidases are mentioned in this review

\begin{tabular}{|c|c|c|c|c|c|c|c|}
\hline Enzyme & \multicolumn{2}{|c|}{ Classification } & \begin{tabular}{|l|}
$\begin{array}{l}\text { Cofactor } \\
\text { occurrence }\end{array}$ \\
\end{tabular} & Tissue distribution & $\begin{array}{l}\begin{array}{l}\text { Substrate } \\
\text { specificity }\end{array} \\
\end{array}$ & Inhibitor & $\begin{array}{l}\text { Physio-pathological } \\
\text { function }\end{array}$ \\
\hline \multirow{4}{*}{$\begin{array}{l}\text { Monoamine } \\
\text { oxidase } \\
\text { (FAD-AO) }\end{array}$} & \multicolumn{2}{|c|}{ MAO-A } & \multirow{4}{*}{ FAD } & \multirow{2}{*}{\begin{tabular}{|l} 
All tissues (outer \\
mitochondrial \\
membrane) \\
Catecholaminergic \\
neurons (MAO-A) \\
Neurons and glial \\
cells \\
(MAO-B)
\end{tabular}} & $\begin{array}{l}\text { Noradrenaline, } \\
\text { serotonin, } \\
\text { tyramine, } \\
\text { tryptamine }\end{array}$ & Clorgyline & \begin{tabular}{|l|} 
Psychiatric- \\
neurological \\
disorders \\
(depression), cardiac \\
cellular degeneration
\end{tabular} \\
\hline & \multicolumn{2}{|c|}{ MAO-B } & & & $\begin{array}{l}\text { Dopamine, } \\
\text { benzylamine, } \\
\text { phenylethylamine, } \\
\text { tyramine, } \\
\text { tryptamine }\end{array}$ & $\begin{array}{l}\text { Selegiline } \\
\text { (L-deprenyl) }\end{array}$ & $\begin{array}{l}\text { Psychiatric- } \\
\text { neurological } \\
\text { disorders } \\
\text { (Parkinson's } \\
\text { disease) }\end{array}$ \\
\hline & \multicolumn{2}{|l|}{ PAO } & & $\begin{array}{l}\text { All tissues } \\
\text { (cytoplasm) }\end{array}$ & $\begin{array}{l}N^{1}- \\
\text { Acetylspermine, } \\
N^{1}, N^{12}- \\
\text { diacetylspermine, } \\
N^{1}- \\
\text { Acetylspermidine, } \\
\text { spermine }\end{array}$ & \multirow[t]{2}{*}{ MDL 72527} & $\begin{array}{l}\text { Homeostatic } \\
\text { regulation of } \\
\text { polyamine pools }\end{array}$ \\
\hline & SMO & & & $\begin{array}{l}\text { All tissues } \\
\text { (peroxisomes) }\end{array}$ & Spermine & & $\begin{array}{l}\text { Polyamine } \\
\text { catabolism signaling } \\
\text { molecule) }\end{array}$ \\
\hline \multirow{4}{*}{$\begin{array}{l}\text { Serum and } \\
\text { tissues } \\
\text { amine } \\
\text { oxidase } \\
\text { (Cu/TPQ- } \\
\mathrm{AO})\end{array}$} & \multicolumn{2}{|c|}{ DAO } & \multirow{3}{*}{$\mathrm{Cu}, \mathrm{TPQ}$} & $\begin{array}{l}\text { Tissues (cytoplasm, } \\
\text { microsomal } \\
\text { fraction), human } \\
\text { placenta, fetal } \\
\text { tissues, neoplastic } \\
\text { processes }\end{array}$ & $\begin{array}{l}1,3- \\
\text { Propanediamine, } \\
\text { putrescine, } \\
\text { cadaverine, } \\
\text { agmatine, } \\
\text { histamine, } \\
\text { spermidine, } \\
\text { spermine }\end{array}$ & \multirow{3}{*}{$\begin{array}{l}\text { Aminoguanidine, } \\
\text { hydrazines, } \\
\text { hydrazides, copper } \\
\text { chelators }\end{array}$} & \multirow[t]{2}{*}{$\begin{array}{l}\text { Cell growth and } \\
\text { differentiation, } \\
\text { detoxification, cell } \\
\text { signaling }\end{array}$} \\
\hline & & BSAO & & Serum & $\begin{array}{l}\text { Benzylamine, } \\
\text { spermine, } \\
\text { spermidine }\end{array}$ & & \\
\hline & SAO & SSAO/VAP1 & & $\begin{array}{l}\text { Biological fluids } \\
\text { and } \\
\text { plasmamembrane } \\
\text { (adipocytes, } \\
\text { placenta, kidney, } \\
\text { liver, spleen) }\end{array}$ & $\begin{array}{l}\text { Benzylamine, } \\
\text { spermine, } \\
\text { spermidine, } \\
\text { aminoacetone, } \\
\text { methylamine }\end{array}$ & & \begin{tabular}{|l|} 
Cell growth and \\
differentiation \\
detoxification, cell \\
signaling, cell \\
adhesion Alzheimer's \\
disease, cerebral \\
amyloid angiopathy, \\
diabetes mellitus, \\
atherosclerosis \\
\end{tabular} \\
\hline & \multicolumn{2}{|l|}{ LOX } & $\mathrm{Cu}, \mathrm{LTQ}$ & $\begin{array}{l}\text { Nuclei of fibrogenic } \\
\text { vascular smooth } \\
\text { muscle cells, } \\
\text { fibroblast }\end{array}$ & $\begin{array}{l}\text { Collagen, elastin } \\
\text { (lysine residues) }\end{array}$ & $\begin{array}{l}\beta \text {-Aminopropionitrile, } \\
\alpha \text {-Aminoguanidine, } \\
\text { hydrazines, } \\
\text { hydrazides, copper } \\
\text { chelators }\end{array}$ & \begin{tabular}{|l|} 
Regulation of \\
collagen and elastin \\
cross-linking, aortic \\
aneurysms, \\
lathyrism, metastatic \\
phenotype tumors, \\
gene regulation \\
\end{tabular} \\
\hline
\end{tabular}

Moreover, MAO-A and MAO-B also exhibit different substrate specificity. It is well known that MAO-A preferentially deaminates aromatic monoamines such as the neurotransmitters noradrenaline and serotonin, whereas MAO-B oxidizes preferentially dopamine, phenylethylamine and benzylamine (Tipton et al. 2004). Tyramine and tryptamine appear to be substrates for both isoforms.

A peroxisomal FAD-dependent enzyme $N^{1}$-acetylpolyamine oxidase (APAO) is a constitutively expressed enzyme that catalyzes the cleavage of acetylated polyamines to produce spermidine (from spermine) or putrescine (from spermidine), 3-aceto-aminopropanal and $\mathrm{H}_{2} \mathrm{O}_{2}$. Wang et al. (2001) identified a gene for an enzyme capable of oxidizing unsubstituted spermine. They initially named the gene PAOhl for the first human polyamine oxidase to be cloned. Vujcic et al. (2002) subsequently confirmed that this new gene/enzyme was also involved in the polyamine catabolic pathway. The new enzyme, named SMO, is a highly inducible FAD-dependent enzyme that oxidizes spermine to produce spermidine, 3-aminopropanal and $\mathrm{H}_{2} \mathrm{O}_{2}$. Interestingly, observations indicate that $\mathrm{SMO}$ might represent an excellent target for chemoprevention 
strategies (Casero and Marton 2007). In fact, using tumornecrosis factor $(\mathrm{TNF} \alpha)$, a pleiotropic inflammatory cytokine, it was shown that this general mediator of inflammation was able to stimulate SMO activity, resulting in a potential damage induced by reactive aldehydes and ROS. The aldehyde, 3-aminopropanal, and $\mathrm{H}_{2} \mathrm{O}_{2}$, once converted into the highly reactive hydroxyl radical (HO) through Fenton-like-catalysis, can damage RNA, DNA, membranes and proteins. A severe damage to DNA, by both enzymatic oxidation products, can lead to mutagenic changes necessary for the development and progression of multiple epithelial cancers. Moreover, $\mathrm{H}_{2} \mathrm{O}_{2}$ formed by polyamine catabolism might play a role as a signaling molecule (Babbar and Casero 2006; Casero and Pegg 2009).

$\mathrm{Cu} / \mathrm{TPQ}-\mathrm{AOs}$ [E.C. 1.4.3.6, amine: oxygen oxidoreductase (deaminating) (copper-containing)] are found in a wide variety of organisms (Mondovì et al. 1989). In microorganisms, $\mathrm{Cu} / \mathrm{TPQ}-\mathrm{AOs}$ generally have a nutritional role utilizing the primary amines as nitrogen or carbon sources. In plants, these proteins are implicated in wound healing and in cell growth by regulating the intracellular di- and polyamine levels, while the aldehyde products might have a key role in the biosynthesis of some alkaloids. In mammals, these enzymes are involved in detoxification and in metabolic and vascular diseases. $\mathrm{Cu}$ /TPQ-AOs are widely present in many organs and tissues, such as vascular smooth cells, adipocytes, placenta, kidney, liver, spleen and plasma showing tissue specificity in different species. Semicarbazide-sensitive amine oxidases (SSAO) belong to this class of $\mathrm{Cu} / \mathrm{TPQ}-\mathrm{AO}$. It was suggested that SSAOs are present in two forms: a membrane-bound form and a soluble form found in plasma (Lyles 1996). The latter, presumably, arises from the proteolytic cleavage of the membrane-bound enzyme, known also as vascular adhesion protein-1 (VAP-1) (Salminen et al. 1998; Stolen et al. 2004; Salmi and Jalkanen 2006).

The soluble $\mathrm{Cu} / \mathrm{TPQ}-\mathrm{AOs}$, also called DAOs, occur in microorganisms (fungi and bacteria), plants, and mammals and those enzymes from bacteria (Parsons et al. 1995; Wilce et al. 1997), yeasts (Li et al. 1998; Duff et al. 2003) and from pea seedlings (Kumar et al. 1996) have been crystallized. In mammals, the best-known enzymes are those from pig kidney and intestine, and from human placenta. DAOs prefer short aliphatic diamines such as putrescine (1,4-diaminobutane) and cadaverine (1,5-diaminopentane) as substrates.

Some mammalian $\mathrm{Cu} / \mathrm{TPQ}-\mathrm{AO}$ s have been characterized structurally, as the human vascular adhesion protein (hVAP1) (Airenne et al. 2005) and the BSAO (Lunelli et al. 2005). Human VAP-1 has been crystallized (Nymalm et al. 2003) but its structure has not been published yet. Models of its structure have been produced by homology modeling using the structures of the $E$. coli and $H$. polymorpha $\mathrm{Cu} / \mathrm{TPQ}-\mathrm{AOs}$
(Salminen et al. 1998; Marti et al. 2004; Yegutkin et al. 2004) that have a sequence identity with hVAP-1 lower than $27 \%$ (Salminen et al. 1998). Conversely, hVAP-1 shows a high sequence identity $(82.5 \%)$ with BSAO. Functional and mechanistic studies on BSAO have yielded limited structural information (Morpurgo et al. 1992; De Biase et al. 1996; Nakamura et al. 1997; Su and Klinman 1998; Bellelli et al. 2000), and its crystal structure has been recently determined (Calderone et al. 2003).

$\mathrm{Cu} / \mathrm{TPQ}-\mathrm{AOs}$ are involved in many physiological processes and metabolic pathways related to biological function of their natural substrates (amines) and reaction products $\left(\mathrm{H}_{2} \mathrm{O}_{2}\right.$ and aldehydes) (Tipton et al. 2003). In mammals, $\mathrm{Cu} / \mathrm{TPQ}-\mathrm{AOs}$ have been associated with cell proliferation, differentiation, development of cells, apoptosis, detoxification and cell signaling. In particular, VAP-1 is involved in glucose uptake and lipolysis in adipocytes, as well as cell adhesion and granulocyte extravasation during inflammation (Lyles 1996; O'Sullivan et al. 2004; Boor et al. 2009). Moreover, the activity of human plasma $\mathrm{Cu} /$ TPQ-AO (the soluble form arising from VAP-1) was found to be altered in a number of disease states, such as inflammatory liver diseases, congestive heart failure, some types of cancer, diabetes mellitus (both type I and type II), and vascular disorders such as atherosclerosis (Tipton et al. 2003; Yu et al. 2003). The formaldehyde generated through the catalytic cycle of SSAO/VAP-1 can form cross links between proteins and contribute to $\beta$-amyloid misfolding and its anomalous deposition in cerebrovascular tissues. It has been hypothesized that SSAO/VAP-1 present in cerebrovascular tissues may be involved in the pathogenesis of Alzheimer's disease and cerebral amyloid angiopathy (Boor et al. 2009).

Lysine tyrosylquinone (LTQ) is present in an other copper-depending amine oxidase, lysyl oxidase (LOX) selectively inhibited by $\beta$-aminopropionitrile. Lysyl oxidase catalyzes the oxidation of specific lysine residues within extracellular elastin and collagen thus generating residues of $\alpha$-aminoadipic- $\delta$-semialdehyde within these proteins. This enzyme (LOX) has been implicated, among several other pathological conditions, in lathyrism and in a number of novel biological functions, including the regulation of the promoter activity of collagen type III, the control of cell adhesion and growth, the metastatic phenotype of certain tumors in adult animals and gene regulation (Lucero et al. 2008; Atsawasuwan et al. 2008).

\section{Polyamine oxidation and catalytic mechanisms of Cu-amine oxidases}

The widespread occurrence of AOs in different organisms and organs suggests their undoubtedly relevant biological 
function in biogenic amine metabolism. The structural and biological functions differ depending on the source of the enzyme. AOs have a physiological role in nutrient metabolism, removing potentially toxic biogenic amines from blood plasma and regulating intracellular spermine and spermidine concentration. In prokaryotes, the AOs allow the microorganisms to use amines as carbon and nitrogen sources, whereas in plants and mammals, the AOs are involved in detoxification processes and regulation of fundamental cellular processes such as tissue differentiation, cell growth and programmed cell death are the main roles (Averill-Bates et al. 2008). In eukaryotes, it is believed that AOs influence cell growth, signaling and development (Green et al. 2002).

From a physiological point of view, two distinct catabolic pathways exist for polyamines: terminal oxidation and interconversion reactions. As a general rule, the former reaction is accomplished by the $\mathrm{Cu} / \mathrm{TPQ}-\mathrm{AOs}$, and the latter one by the FAD-enzymes. However, this distinction is not absolute; in fact, spermine and spermidine, oxidized by $\mathrm{Cu} / \mathrm{TPQ}-\mathrm{AO}$, may undergo spontaneous degradation when not previously further oxidized by aldehyde dehydrogenases, forming spermidine and putrescine, respectively, with formation of the aldehyde acrolein. organism. It is found in both the cytosolic and peroxisome fractions. Natural substrates of PAO, in the order of their affinity to the enzyme, are $N^{1}$-acetylspermine, $N^{1}, N^{12}$-diacetylspermine, $N^{1}$-acetylspermidine, spermine (Seiler 2000). Homogenates of adult rat brain, with low PAO activity, catalyze the oxidative degradation of both $N^{1}$ acetylspermine and $N^{1}, N^{12}$-diacetylspermine. The selective inactivation of PAO by $N^{1}, N^{4}$-bis(2,3-butadienyl)-1,4butanediamine (MDL 72527) inhibits the polyamine oxidation (Bey et al. 1985). In contrast, Cu/TPQ-AOs activity is present at considerably different levels in various tissues and organs. $\mathrm{Cu} / \mathrm{TPQ}-\mathrm{AOs}$ have both intracellular and extracellular localization, being present in serum and in some biological fluids.

Diamine oxidases are tissue-specific $\mathrm{Cu} / \mathrm{TPQ}-\mathrm{AOs}$. Their preferred substrates are diamines (1,3-propanediamine, putrescine, cadaverine, agmatine, histamine), but spermidine and spermine are also substrates (Seiler 1994). Their role is in the terminal polyamine catabolism to metabolize the polyamines into products which can be excreted in the urine (Seiler 2000). Diamine oxidases oxidatively deaminate the aminopropyl moieties of spermidine and spermine and also the aminobutyl moiety of spermidine. Reaction products are aminoaldehydes, $\mathrm{H}_{2} \mathrm{O}_{2}$

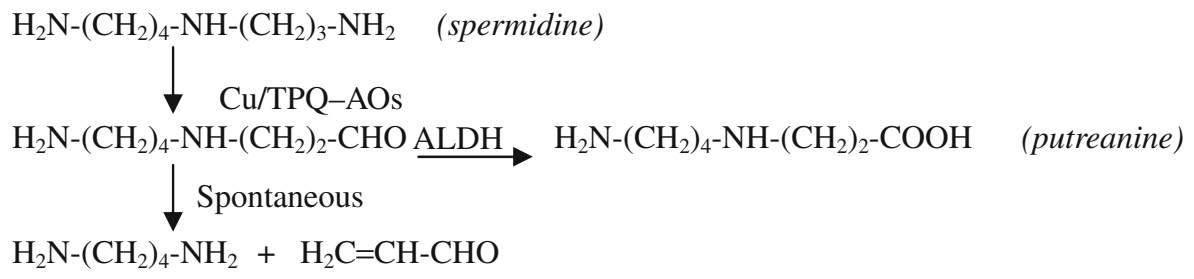

Moreover, some AOs isolated from bacteria and plants, which cleave polyamines (PAO), at the secondary nitrogen to form 1,3-diaminopropane (instead of putrescine) as reaction product, which is not reutilized for re-synthesis of higher polyamines.

$\mathrm{H}_{2} \mathrm{~N}-\left(\mathrm{CH}_{2}\right)_{4}-\mathrm{NH}-\left(\mathrm{CH}_{2}\right)_{3}-\mathrm{NH}_{2}$

(spermidine)

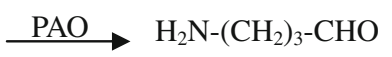

(4-aminobutyraldehyde) and ammonia. Cells usually contain sufficient amount of aldehyde dehydrogenase activities as to allow the rapid conversion of the aminoaldehydes into the corresponding amino acids. Diamine oxidases are especially elevated in rapidly proliferating tissues, such as placenta, fetal tissues

$+\mathrm{H}_{2} \mathrm{~N}-\left(\mathrm{CH}_{2}\right)_{3}-\mathrm{NH}_{2}$

(1,3-diaminopropane)
Disregarding these minor exceptions, this distinction of the polyamine oxidative reactions suggests a different physiological significance for the FAD- and $\mathrm{Cu}$-dependent enzymes in tissues and biological fluids. FAD-dependent PAO, which is integrated into the interconversion pathway, was purified from several sources. PAO is present at high activity in nearly all cells and organs of the vertebrate and organs undergoing hyperplastic, hypertrophic or neoplastic processes and they are abundant in the kidney cortex of several animal species, including man. Their presence in the proximal convoluted tubules epithelium would imply a role as biogenic amine scavenger.

Under physiological conditions, $\mathrm{Cu} / \mathrm{TPQ}-\mathrm{AO}$ activity is present in the serum of swine, bovine and other animals, 
but was not detected in horse and human. In man, serum amine oxidase activity rises during pregnancy or under some pathological conditions, such as cancer.

Serum $\mathrm{Cu} / \mathrm{TPQ}-\mathrm{AOs}$ oxidatively deaminate diamines and polyamines. Swine serum AO deaminates diamines and exhibits histaminase activity. Instead, in human pregnancy serum, it seems to deaminate both diamines and polyamines (Gahl and Pitot 1982a; Gahl et al. 1982b). Bovine serum amine oxidase, a copper-containing glycoprotein weighing $170 \mathrm{kDa}$, is the prototype of mammalian Cu/TPQ-AOs (Houen 1999; Agostinelli et al. 2004, 2005). Bovine serum amine oxidase is the first enzyme found to oxidatively deaminate the primary amino groups of polyamines, such as spermine and spermidine, as shown in Fig. 1 (Agostinelli et al. 2006a). The reaction of spermidine is the same to that mentioned above for DAO. However, only the aminopropyl moiety of spermidine is oxidatively deaminated by BSAO (Tabor et al. 1964). The presumed formation of acrolein has been included into Fig. 1 (Alarcon 1970).

Overall, Cu/TPQ-AOs have relatively broad substrate specificities (e.g., benzylamine and heptylamine) and oxidize several other naturally occurring and synthetic amines, although with greatly varying values of $K_{\mathrm{M}}$ and $k_{\text {cat }}$.

The activities of $\mathrm{Cu} / \mathrm{TPQ}-\mathrm{AO}$ with specificity for spermidine and spermine are low in humans and most mammals. Except in ruminants they seem not to play a major role in polyamine degradation. The physiological function of BSAO is presumably removal of excessive spermidine from the blood, spermidine that was liberated from bacteria (Cohen 1998).

$\mathrm{Cu} / \mathrm{TPQ}-\mathrm{AOs}$ share some fundamental structural properties. All serum amine oxidases are homodimers and have similar molecular organizations with 33 fully conserved residues close to the catalytic site. The peptide chains of the enzymes from different sources are sialylated to different degrees. Recently, the crystal structure of desialylated BSAO has been reported at $2.37 \AA$ resolution (Lunelli et al. 2005). Each of the identical subunit $\left(M_{r} 85 \mathrm{kDa}\right)$ contains in the active site one tightly bound $\mathrm{Cu}^{2+}$ coordinated to three His residues, and TPQ, which is part of the consensus sequence [Asn-TPQ-Asp (or Glu)] of the peptide chain (Mu et al. 1992; Mitchell Guss et al. 2009).

The catalytic mechanism involves the formation of a Schiff base between the amine substrate and the oxidized TPQ that is followed by an intramolecular rearrangement of the double bonds. An aldehyde is released by a hydrolytic step. The oxidized form of Cu/TPQ-AOs has a distinctive pink color and absorbs in the visible region between 476 and $498 \mathrm{~nm}$ (Agostinelli et al. 2005). The organic cofactor in the reduced state (colorless) has at this stage an amino nitrogen covalently bound. Re-oxidation of TPQ by $\mathrm{O}_{2}$ releases ammonia and $\mathrm{H}_{2} \mathrm{O}_{2}$, and closes the cycle (Janes and Klinman 1991). The order of substrate addition and product release is therefore fixed and no ternary complex is formed, as in the ping-pong type mechanisms (Hartmann and Klinman 1991; Bellelli et al. 2000). Thus, the catalytic cycle can be divided into two halfreactions: enzyme reduction by substrate at the quinine moiety (TPQ-TPQH2) (Eq. 1) and its re-oxidation by molecular oxygen according to the reactions (Eq. 2):

$\mathrm{E}_{\mathrm{ox}}+\mathrm{R}-\mathrm{CH}_{2}-\mathrm{NH}_{3}^{+} \rightarrow \mathrm{E}_{\text {red }}-\mathrm{NH}_{3}^{+}+\mathrm{R}-\mathrm{CHO}$

$\mathrm{E}_{\text {red }}-\mathrm{NH}_{3}^{+}+\mathrm{O}_{2} \rightarrow \mathrm{E}_{\mathrm{ox}}+\mathrm{NH}_{4}^{+}+\mathrm{H}_{2} \mathrm{O}_{2}$

In plant enzyme, the substrate-reduced colorless $\mathrm{Cu}^{\mathrm{II}}$-aminoquinol equilibrates rapidly with the $\mathrm{Cu}^{\mathrm{I}}$ semiquinolamine cation radical species by transferring one electron to copper, which is in turn reduced from the cupric to the cuprous state, and the solution immediately turns yellow as a result of the formation of new absorption bands centered at 464, 434 and $360 \mathrm{~nm}$ (Agostinelli et al. 2005, 2009a). On the contrary, mammalian Cu/TPQ-AOs, which are not formed in the radical species during the normal catalytic cycle, remain in the reduced aminoquinol form (Agostinelli et al. 2005). The second half-reaction involves the re-oxidation of the enzyme with the contemporaneous release of ammonia and hydrogen peroxide.

Therefore, $\mathrm{Cu}^{2+}$ appears to play an important role in both the formation of the reduced enzyme species and its re-oxidation, and it appears to control the transfer of the substrate from a hydrophobic binding site near the protein surface to the deeply buried active site (Agostinelli et al. 1997; Parsons et al. 1995; Kumar et al. 1996). $\mathrm{Cu}^{2+}$ has also a structural function (Agostinelli et al. 1994a).

As described above, in the case of spermidine and spermine, the primary amino group of the aminopropyl moiety is preferentially deaminated by BSAO, to form the respective mono- and the unstable di-aldehydes intermediate $\left[N, N^{1}\right.$-bis(3-propionaldehyde)-1,4-butanediamine $]$ (Tabor et al. 1964; Lee and Sayre 1998), but reaction of the secondary amino groups of spermine with purified BSAO has also been described (Houen 1999). In conclusion, as shown in Fig. 1, the reaction involves dioxygen and water as substrates (Tabor and Tabor 1984) while the products are $\mathrm{H}_{2} \mathrm{O}_{2}$, aldehydes and ammonia (Tabor and Tabor 1984; Tabor et al. 1964). The aldehydes have been identified and studied for their biological properties (see, e.g., Tabor et al. 1964). The formation of acrolein from these aldehydes by spontaneous $\beta$-elimination was first postulated by Alarcon (1970), but has long been debated. It was particularly questioned by Israel et al. (1973), based on experiments with synthetic aldehydes. Recent work is in favor of the formation of acrolein as a product of BSAO-catalyzed 
oxidation of spermidine and spermine in cell cultures, as will be described in the next paragraphs (Sharmin et al. 2001; Agostinelli et al. 2006a, 2009b; Averill-Bates et al. 2008). In the presence of suitable enzymes the aldehydes may be oxidized to the corresponding amino acids, or reduced to alcohols (for details of catabolism see Seiler 1992, 2004).

\section{Polyamine enzymatic oxidation products induce cell death}

The natural polyamines putrescine, spermidine and spermine are in multiple ways involved in cell growth and maintenance of cell viability. Moreover, polyamines are also involved in events inherent to genetically programmed cell death (Seiler and Raul 2005). In fact, intracellular concentrations of polyamines are highly regulated. If they accumulate excessively within the cells, due to either very high extracellular concentrations or deregulation of the homeostatic mechanisms, polyamines can cause cytotoxic effects (Wallace and Fraser 2003). Thus, Cu/TPQ-AOs are important enzymes contributing to the regulation of the levels of polyamines catalyzing their oxidative deamination. Spermidine and spermine may so become a source of toxic metabolites (Arancia et al. 2004) and findings suggest that cytotoxic enzymatic oxidation products of spermine, formed in situ by a $\mathrm{Cu} / \mathrm{TPQ}-\mathrm{AO}$-catalyzed reaction, might be lethal for tumors (Averill-Bates et al. 2005; Agostinelli et al. 2006a, b, c). It was determined that polyamine concentrations are high in rapidly growing tissues such as the breast and colon cancers (Heby and Persson 1990). The oxidation of spermine by BSAO generates cytotoxic products, $\mathrm{H}_{2} \mathrm{O}_{2}$ and aldehyde(s), that have been implicated in programmed cell death, induction of cytotoxicity, inhibition of cell growth (Bachrach et al. 1987; Henle et al. 1986). These metabolites can also induce either apoptosis or necrosis, depending on both their concentrations and the cell type (Lindsay and Wallace 1999; Calcabrini et al. 2002; Agostinelli and Seiler 2006; Averill-Bates et al. 2005).

It was previously reported that purified BSAO and exogenous spermine can induce inhibition of cell proliferation, severe glutathione depletion and cell death in Chinese hamster ovary $(\mathrm{CHO})$ cells (Averill-Bates et al. 1993; Agostinelli et al. 1996). Cytotoxicity was also observed in several human tumor cell lines of LoVo and M14 (Calcabrini et al. 2002; Agostinelli et al. 2006a). The cytotoxic effect induced by the enzymatic system (spermine and BSAO) appeared to be mediated by the oxidation products, $\mathrm{H}_{2} \mathrm{O}_{2}$ and aminodialdehyde or acrolein. The mechanism of cell death of DX (doxorubicin)-sensitive and -resistant human colon adenocarcinoma and melanoma cancer cells, induced by the enzymatic toxic products, was evaluated by plating efficiency assay (Fig. 2) and the ultrastructural alterations were investigated by transmission electron microscopy (TEM) (Fig. 3) (Calcabrini et al. 2002; Agostinelli et al. 2006a, b, 2009b).

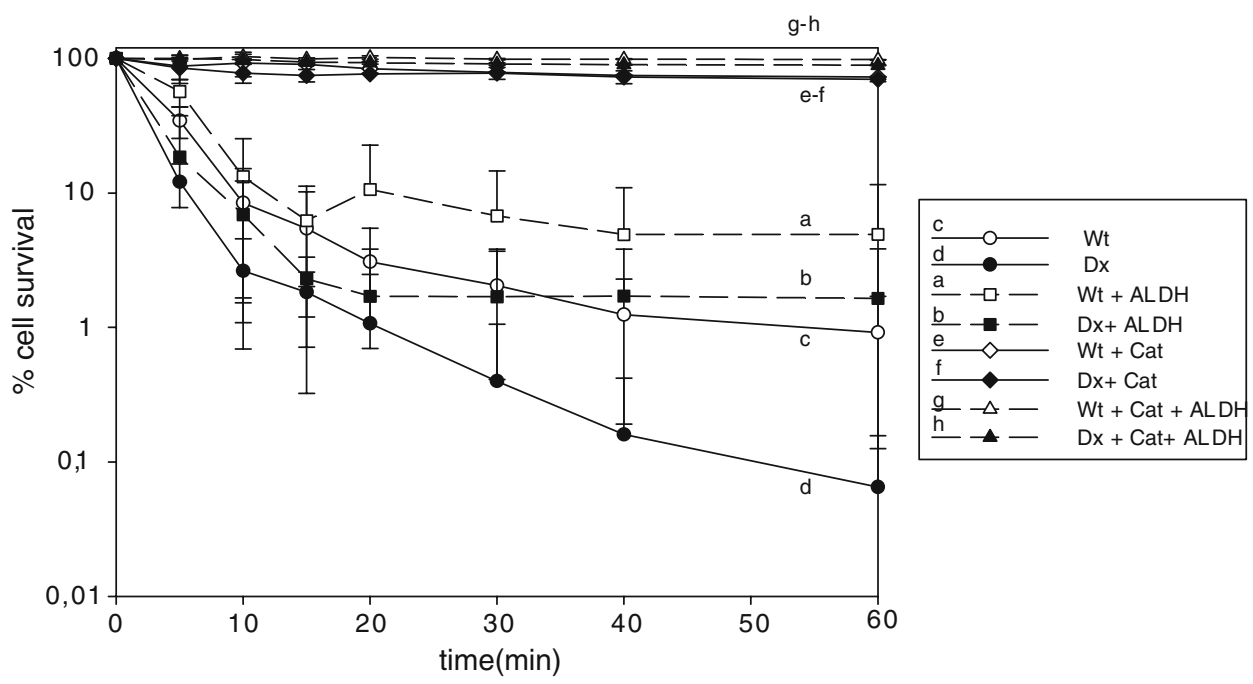

Fig. 2 Effect of catalase and aldehyde dehydrogenase on cytotoxicity induced by BSAO in the presence of spermine. LoVo WT (open symbols) and LoVo DX (solid symbols) cells were incubated at $37^{\circ} \mathrm{C}$ for $60 \mathrm{~min}$ with purified BSAO $\left(6.50 \times 10^{-3} \mathrm{U} / \mathrm{ml}\right)$ and exogenous spermine $12 \mu \mathrm{M}$ without (open circle; filled circle) or with catalase $240 \mathrm{U} / \mathrm{ml}$ (solid lines with open diamond; solid lines with filled diamond), with ALDH $0.4 \mathrm{U} / \mathrm{ml}$ (dashed lines with open square; dashed lines with filled square) and with catalase and ALDH (dashed lines with open triangle; dashed lines with filled triangle). Mean \pm SD are shown for two to six estimations from four to six experiments. When not shown, SD lie within symbols 
Fig. 3 Transmission electron microscopic observations. a Control LoVo WT and b control LoVo DX cell; c LoVo WT and d LoVo DX cell after incubation for $1 \mathrm{~h}$ at $42^{\circ} \mathrm{C}$; e LoVo WT and f LoVo DX cell treated with BSAO and $6 \mu \mathrm{M}$ spermine at $42^{\circ} \mathrm{C}$. Alterations of the mitochondrial structure were more evident in treated resistant cells.

Moreover, the treatment with BSAO-spermine under hyperthermic conditions produced very severe structural damages, particularly at mitochondrial level (f). Scale bars $0.5 \mu \mathrm{m}$

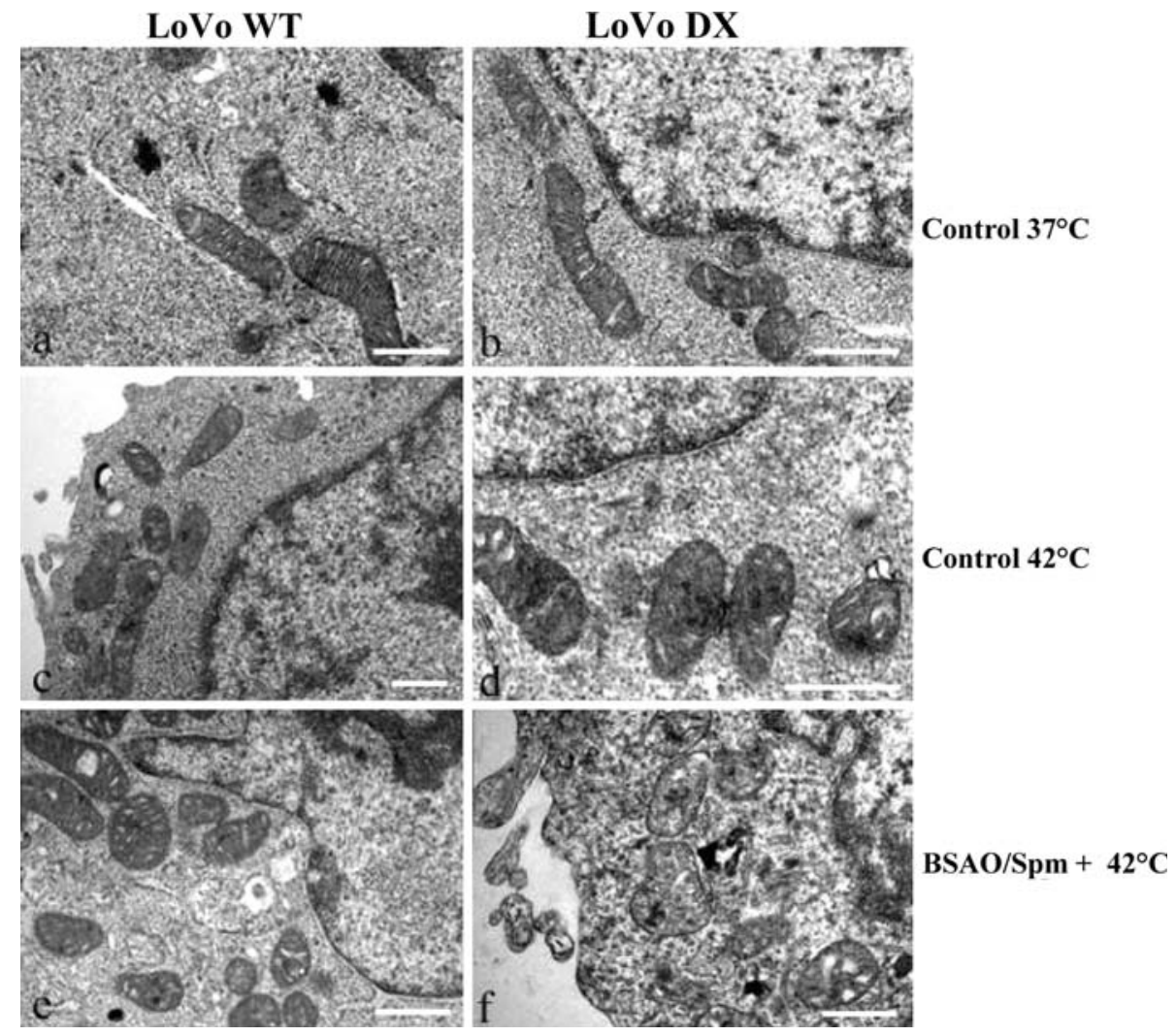

Consistent with previous observations on P-glycoprotein overexpressing MDR CHO cells (Lord-Fontaine et al. 2001), further studies demonstrated that $\mathrm{H}_{2} \mathrm{O}_{2}$ and aldehyde(s), the products of BSAO-catalyzed oxidation of spermine, were also able to overcome multidrug resistance (MDR) in both LoVo DX and M14 ADR cancer cells (Calcabrini et al. 2002; Arancia et al. 2004; Agostinelli et al. 2006a, b, c, 2009b). Interestingly, both MDR cell types are significantly more sensitive to cytotoxic spermine metabolites than their corresponding wild-type (WT) counterparts. This is of particular interest, since one of the problems of conventional anticancer therapy is development of drug resistance. This phenomenon, following exposure to cytotoxic drugs, is a major obstacle of conventional anticancer chemotherapy. MDR is associated with phenotypic alterations. MDR cancer cells usually display a decrease in intracellular drug accumulation and/ or drug distribution due to the over-expression of genes, which encode membrane-bound transporter proteins, such as a $170 \mathrm{kDa}$ P-glycoprotein (P-gp) (Gervasoni et al. 1991; Arancia et al. 1998). P-Glycoprotein functions as an energy-dependent pump, that expels drugs out of cells (Gottesman and Pastan 1993).

Figure 2 shows the percentage cell survival against the time of exposure to purified BSAO $\left(6.50 \times 10^{-3} \mathrm{U} / \mathrm{ml}\right)$ in the presence of exogenous spermine $(12 \mu \mathrm{M})$, with catalase
$240 \mathrm{U} / \mathrm{ml}$ (curves e-f), with ALDH $0.4 \mathrm{U} / \mathrm{ml}$ (curves a-b) and with both catalase and ALDH (curves $\mathrm{g}-\mathrm{h}$ ), at $37^{\circ} \mathrm{C}$. In the presence of BSAO and spermine alone, a higher cytotoxicity was observed in LoVo DX than in LoVo WT cells. The percentage cell survival decreased in both cell lines with increasing exposure time, resulting in approx. $0.92 \%$ in LoVo WT (curve c) and approx. $0.065 \%$ in LoVo DX cells (curve d), after $60 \mathrm{~min}$ of incubation.

In order to evaluate the contribution of each enzymatic oxidation product in the inhibition of cell growth, experiments were performed in the presence of exogenous catalase, an enzyme that decomposes $\mathrm{H}_{2} \mathrm{O}_{2}$ or catalase and ALDH added simultaneously to the incubation mixture. Catalase $(240 \mathrm{U} / \mathrm{ml})$ afforded a marked reduction of the cytotoxic effect, corresponding to approx. $80 \%$ cell survival, on LoVo WT and LoVo DX cells (curves e and f, respectively), probably due to the degradation of $\mathrm{H}_{2} \mathrm{O}_{2}$, formed in the catalytic reaction by the enzyme. The result suggested that $\mathrm{H}_{2} \mathrm{O}_{2}$ was not the sole toxic factor and that other products of the enzymatic oxidative deamination were involved, such as aldehyde(s), including acrolein spontaneously formed from the aminoaldehydes (Sharmin et al. 2001; Averill-Bates et al. 2008; Agostinelli et al. 2009b). The addition of exogenous NAD-dependent ALDH $(0.4 \mathrm{U} / \mathrm{ml})$ alone to metabolize the aldehyde to the corresponding carboxylic acid, had partial effects on survival 
presumably by preventing the toxic effects of acrolein (curves a and b, respectively).

Fluorimetric determinations showed that about $80 \%$ of $\mathrm{H}_{2} \mathrm{O}_{2}$ formed by BSAO cross the cell membrane of LoVo cells, and the uptake reached a maximum about $10 \mathrm{~min}$ after the enzymatic reaction was started (Calcabrini et al. 2002). In fact, the addition of exogenous catalase to the culture medium prevented the loss of about $80 \%$ viable cells, advocating for $\mathrm{H}_{2} \mathrm{O}_{2}$ as the most important cytotoxic metabolite of spermine in our experimental setting. Several findings support this view (Calcabrini et al. 2002; Agostinelli et al. 2007b; Averill-Bates et al. 2008). Moreover, the experiments showed that the residual cytotoxicity was due to the other reaction product, aminodialdehyde or acrolein. In fact, there is an ongoing debate about the question whether $\mathrm{H}_{2} \mathrm{O}_{2}$ or the spermine-derived aldehydes are the major effectors. While a contribution of the aldehydes is undoubted, it is still an open question which sperminederived aldehyde is most important. According to Sharmin et al. (2001), acrolein, formed by spontaneous $\beta$-elimination (Fig. 1), is among the spermine metabolites nearly exclusively responsible for the induction of cell death. However, a role of acrolein in the early, most active phase of cell damage is unlikely, because its spontaneous formation from the aldehydes deriving from spermine is a time-dependent process of unknown velocity, while in contrast $\mathrm{H}_{2} \mathrm{O}_{2}$ is produced immediately at the beginning of the enzymatic reaction (Agostinelli et al. 1994b; Calcabrini et al. 2002; Agostinelli et al. 2006a). The prevention of cytotoxicity of spermine metabolites by catalase and ALDH, separately added to the incubation mixture confirmed these results (Fig. 2 curves e, $\mathrm{f}$, a and b). In addition, the simultaneous presence of both exogenous enzymes, catalase and NAD-dependent ALDH, completely inhibited cytotoxicity (approx. 97\%) throughout the $60 \mathrm{~min}$ of incubation (Fig. 2 curves g and h) (Calcabrini et al. 2002; Agostinelli et al. 2007b; Averill-Bates et al. 2008) .

In order to reveal the intracellular targets involved in the mechanisms responsible for the higher cytotoxic effect of the enzymatic products on the drug-resistant cells, TEM observations and cytofluorimetric analysis were carried out. These studies revealed major pathological modifications of the mitochondria.

Both control LoVo WT (Fig. 3a) and LoVo DX cells (Fig. 3b) showed a well-preserved ultrastructure when observed by $\mathrm{TEM}$, at $37^{\circ} \mathrm{C}$. The nucleus was clearly defined with dispersed chromatin, while the cytoplasm was characterized by the presence of mitochondria with parallel cristae in a dense and uniform matrix. After treatment with BSAO and $6 \mu \mathrm{M}$ spermine, at $42^{\circ} \mathrm{C}$, LoVo WT cells did not show any consistent ultrastructural alteration (Fig. 3e). In contrast, MDR cells exhibited marked modifications; in particular, all mitochondria showed a highly condensed matrix and dilated cristae (Fig. 3f) (Calcabrini et al. 2002; Agostinelli et al. 2006b).

Mitochondria, therefore appear to play a pivotal role in determining the differential response between sensitive and drug-resistant cells. The higher sensitivity to cytotoxic spermine derivatives observed in LoVo DX cells, by flow cytometric analysis, was attributed to an earlier and higher mitochondrial membrane depolarization. Moreover, a higher basal production of ROS was detected in MDR cells than in the drug-sensitive cells, suggesting an increased interaction of ROS with mitochondrial electron transport chain in drug-resistant cells. In fact, $\mathrm{H}_{2} \mathrm{O}_{2}$ could directly interact with some iron of $\mathrm{Fe} / \mathrm{S}$ centres located in the mitochondrial respiratory chain, raising the highly reactive hydroxyl radical ( $\mathrm{HO}^{\circ}$ ) by means of Fenton reaction, and thereby may induce oxidation of some thiol ( $\mathrm{SH}$ ) groups, proteins and lipids. These events lead to mitochondrial permeability transition induction and consequent bioenergetic collapse, redox catastrophe and apoptosis (Calcabrini et al. 2002; Arancia et al. 2004; Toninello et al. 2004).

\section{Polyamine metabolites in therapeutic applications}

During the past decades, considerable research has been devoted to the discovery of new and more effective pharmacological agents for clinical antitumor therapy, involving the polyamine pathway. Inhibitors of ornithine decarboxylase, such as difluoromethylornithine (DFMO), and agents that stimulate polyamine acetylation and export, such as non-steroidal anti-inflammatory drugs (NSAIDS), act at least additively to arrest growth in human cells models and suppress intestinal carcinogenesis in mice (Gerner et al. 2007; Babbar and Casero 2006). A phase III clinical trial assessed the recurrence of adenomatous polyps after treatment with DFMO plus sulindac or matched placebos (Mc Laren et al. 2008). A prospective, randomized, placebo-controlled clinical trial of combination DFMO and sulindac, a non-steroidal antiinflammatory drug, found that the 36-month treatment was associated with an evident reduction of recurrence of all adenomas, and over a $90 \%$ reduction of recurrence of advanced and/or multiple adenomas, without evidence of serious toxicities in essentially healthy participants involved in the trials (Simoneau et al. 2008; Gerner and Meyskens 2009).

In this context, toxic polyamine metabolites are currently explored as probable candidates for a new strategy in tumor therapy (Agostinelli et al. 2004, 2007b; Agostinelli and Seiler 2006), since it has been observed that the growth of a mouse melanoma (B16-F0) was inhibited by exposure to BSAO and spermine (Averill-Bates et al. 2005, 2008). This may be achieved by combinations of the treatment 
Fig. 4 Time course for temperature and spermine concentration dependence on cytotoxicity of BSAO $\left(6.5 \times 10^{-3} \mathrm{U} / \mathrm{ml}\right)$ in the presence of spermine $12 \mu \mathrm{M}$ on percentage cell survival in LoVo WT (open symbols) and LoVo DX (solid symbols) cells during $60 \mathrm{~min}$ at $37^{\circ} \mathrm{C}$ (solid lines with open circle; solid lines with filled circle) and at $42^{\circ} \mathrm{C}$ (dashed lines with open triangle; dashed lines with filled triangle). Mean $\pm \mathrm{SD}$ are shown for two to six estimations for four to six experiments. When not shown, SD lie within the symbols

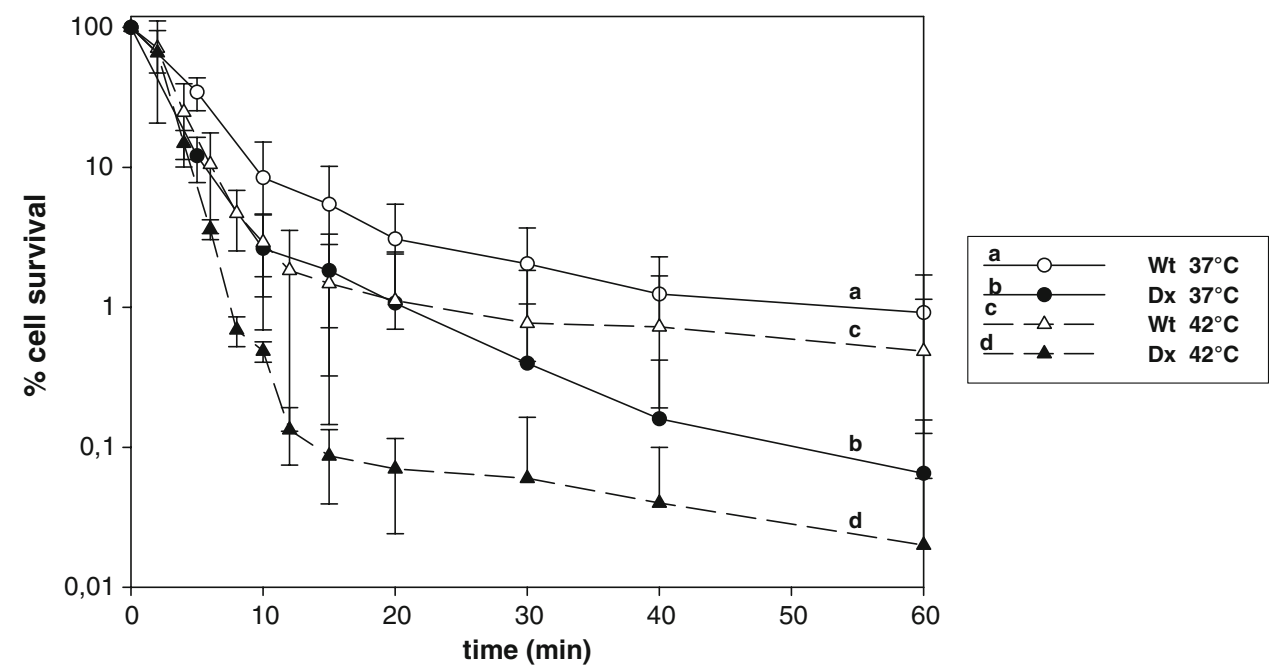

with cytotoxic drugs, or by heat. Hyperthermia in combination with cytotoxic drugs, preferentially with drugs that enhance cytotoxicity at elevated temperature (Urano et al. 1999), and the administration of drug combinations are clinically accepted methods.

The data in Fig. 4 show that $\mathrm{H}_{2} \mathrm{O}_{2}$ and aldehyde (produced by the $\mathrm{BSAO} /$ polyamine-spermine enzymatic system) induce greater cytotoxicity at $42^{\circ} \mathrm{C}$ (curves $\mathrm{c}$ and d), than at $37^{\circ} \mathrm{C}$ (curves a and b) and in MDR human cancer (LoVo and M14) cells compared to the sensitive ones. These findings were supported by TEM observations. The treatment with BSAO and $6 \mu \mathrm{M}$ spermine under hyperthermic conditions induced severe alterations in both wildtype (Fig. 3e) and MDR (Fig. 3f) cells and the changes appeared to be much more pronounced in resistant cells (Agostinelli et al. 1994b, 2006a, b). In fact, localized hyperthermia enhances the cytotoxicity of several antitumoral drugs and has considerable potential in cancer therapy (Bates and Mackillop 1990).

Therefore, hyperthermia could act at the initial stage of the treatment, probably by accelerating the kinetics of the membrane molecular interactions and by favoring drug delivery into the tumor mass (Agostinelli et al. 1995).

Promising results are emerging from clinical studies involving hyperthermia combined with chemotherapy (Issels 1999). A biological strategy to enhance the therapeutic effects of hyperthermia is to use heat together with pharmacological agents that become much more cytotoxic at high temperatures. The compounds, such as cysteamine and aminothiol $\mathrm{N}$-(2-mercaptoethyl)-1,3-propanediamine (WR 1065), defined as thermosensitizers (Nagele et al. 1990), are not toxic at $37^{\circ} \mathrm{C}$, but at elevated temperatures they become potent cell inactivators (Hahn 1982). Another group of drugs, all of which were considered to be heat sensitizers, are the naturally occurring polyamines putrescine, spermine and spermidine (Gerner et al. 1980). Several findings clearly showed the essential role of enzymatic oxidation products of polyamines (Agostinelli et al. 1994b, 2006a, 2009b; Averill-Bates et al. 2008; Calcabrini et al. 2002; Arancia et al. 2004; Henle et al. 1986), rather than polyamines themselves, in causing cytotoxicity (Ben-Hur et al. 1978). Interestingly, spermine at concentrations $\leq 1 \mu \mathrm{M}$, in the presence of BSAO, was not toxic at $37^{\circ} \mathrm{C}$ on both LoVo and M14 cells, but became cytotoxic at $42^{\circ} \mathrm{C}$ and behaved similarly to the abovereported thermosensitizers (Agostinelli et al. 2006b, 2009b). Beneficial effects could therefore be achieved using localized heating to enhance the action of toxic products generated by $\mathrm{BSAO} /$ spermine within the tumor region, without increasing normal tissue damage.

Currently, we are studying drug combinations with the aim of increasing cell death by toxic polyamine metabolites. The cytotoxicity of BSAO/spermine was enhanced by pre-treatment of the cells with MDL 72527. This compound is an inactivator of FAD-dependent polyamine oxidase and represents a lysosomotropic compound (Dai et al. 1999). It was demonstrated to improve the antitumor effect of DFMO (Seiler et al. 2002) which is undergoing clinical evaluation as a chemoprevention agent (Gerner et al. 2007; Wallace and Niiranen 2007; Gerner and Meyskens, 2009).

MDL 72527 has cytotoxic properties which are unrelated to its ability to inactivate PAO (Seiler et al. 2002). Cell survival experiments were therefore performed on LoVo and M14 cells. In the investigation, emphasis was placed on the ability of MDL 72527 to sensitize both cell lines to $\mathrm{H}_{2} \mathrm{O}_{2}$ and aldehyde generated from $\mathrm{BSAO} /$ spermine. Pre-treatment with MDL 72527 sensitized both WT and MDR LoVo and M14 cell lines to the subsequent exposure to spermine metabolites. The lowest cell survival 
was observed after $24 \mathrm{~h}$ of pre-incubation with MDL 72527. Cytotoxicity was significantly greater by the combined treatment than by $\mathrm{BSAO} /$ spermine alone. An impairment of cell metabolism by this drug was indicated by the formation of numerous cytoplasmic vacuoles of lysosomal origin within $6 \mathrm{~h}$. Mitochondrial damage, as observed by TEM, seemed to correlate better with the cytotoxic effects than the formation of vacuoles (Agostinelli et al. 2006a, c). These vacuoles are most probably of lysosomal origin and their formation did not correlate directly with the loss of cell viability. Instead, the results support the hypothesis that the release of lysosomal enzymes into the cytosol by MDL 72527 is responsible for its sensitizing effect. In fact, it is known that the release of lysosomal enzymes produces oxidative stress and an important role of lysosomes in both necrotic and apoptotic cell death is well founded (Guicciardi et al. 2004). Regarding the impairment of cell viability, the mitochondrial ultrastructural alterations of the cells treated with $\mathrm{BSAO/spermine,} \mathrm{after} \mathrm{pre-treatment} \mathrm{with} \mathrm{MDL} \mathrm{72527,}$ seem more relevant than the formation of cytoplasmic vacuoles, since they were more accentuated in MDR cells than in the wild-type ones. Moreover, they seem to correlate with the loss of cell viability (Agostinelli et al. 2009b). It was reported that one of the earliest signs of cell damage by BSAO and spermine is the depolarization of the mitochondrial membranes (Arancia et al. 2004).

Therefore, owing to its lysosomotropic effect, pretreatment with MDL 72527 amplifies the ability of the metabolites formed from spermine by oxidative deamination to induce cell death.

In fact, the results suggest that enzymatically formed cytotoxic agents alone, or in combination with either the polyamine oxidase inactivator (MDL 72527) or heat treatment, activate stress signal transduction pathways, leading to apoptotic cell death. These findings suggest that lysosomotropic compounds are of interest as anticancer agents, mainly in the treatment of MDR tumors (Agostinelli and Seiler 2007).

\section{Conclusions and perspectives}

From a therapeutic point of view, the improvement of the efficacy of in situ formation of cytotoxic polyamine metabolites is essential. Therefore, the use of amine oxidase to generate enzymatic toxic products deserves to be considered in cancer therapy (Agostinelli et al. 2004). In the previous studies, $\mathrm{H}_{2} \mathrm{O}_{2}$ and aldehydes were produced outside the cells and subsequently they entered the cells, inducing cytotoxic effects (Calcabrini et al. 2002). This approach has the advantage that it only requires a small amount of the enzyme protein for toxin formation, and that the cytotoxic reaction products are continuously formed over an extended period of time (Agostinelli and Seiler 2006).

Since endogenous polyamines are present at high concentrations in tumor cells and growing tissues (Heby and Persson 1990), it is expected that by delivering BSAO into cancer cells, toxic enzymatic oxidation products could be produced intracellularly for selective in situ killing of the same cells. Therefore, strategies could be developed for the intracellular delivery of the enzyme in vivo, for possible clinical application. In fact, in cultured normal chick fibroblasts or in fibroblasts transformed by Rous sarcoma viruses, Bachrach et al. (1987) observed an inhibition of the synthesis of proteins and nucleic acids when the cells were microinjected with amine oxidase.

Transformed cells were more sensitive than normal controls, presumably due to higher polyamine content. Moreover, attempts were made to incorporate the enzyme into liposomal vesicles (Agostinelli et al. 1988), and to prepare amine oxidase-gold complexes that are bound and incorporated by hepatocytes (Dini et al. 1991). Thus, endogenous polyamines could be targeted and oxidized by the exogenously introduced BSAO enzyme.

However, the in situ formation of toxic compounds or radicals by enzyme catalyzed reactions is a promising start. Our attention was particularly focused on another strategy, currently under further investigation, to produce an immobilized BSAO with the aim to increase its plasmatic half-life and therapeutic efficacy and to decrease drug toxicity.

The antitumor potential of BSAO was therefore evaluated in vivo, using a B16 mouse melanoma model in C57BL mice. BSAO, when directly injected into the solid tumors, was able to induce tumoricidal activity by converting endogenous polyamines to toxic products in situ (Averill-Bates et al. 2005). The enzyme was administered in its native form and also immobilized in a biocompatible polymer composed of bovine serum albumin and polyethylene glycol (PEG). The immobilized enzyme showed higher operational stability and functional activities, relative to its native form (Demers et al. 2001). When immobilized BSAO was injected into the tumor, there was a marked decrease $(70 \%)$ in tumor growth, compared to a decrease of $32 \%$ of tumor size when native BSAO was administered. The mechanisms of cell death were determined in vivo (Averill-Bates et al. 2005). When tumors were treated with immobilized BSAO, there was a high level of apoptotic cell death (around 70\%), compared to less than $10 \%$ with the native enzyme. Native BSAO induced a high level of necrosis (around 40\%), compared to less than $10 \%$ with immobilized BSAO, probably due to a burst of cytotoxic products. The advantage of the immobilized BSAO is that it allows the slow release of cytotoxic 
products and thereby induces tumor cell death by apoptosis rather than necrosis, thus decreasing inflammatory damage to surrounding tissues (Averill-Bates et al. 2005, 2008; Casero and Marton 2007).

The immobilization of BSAO on other hydrogel polymers such as arginate/chitosan (less than $5 \mu \mathrm{m}$ of diameter) will be also performed. In this regard, we are also developing new BSAO delivery systems based on the encapsulation of the enzyme in tumor-specific nano-technological envelops (Nayvelt et al. 2007).

In conclusion, the toxic enzymatic oxidation products generated by BSAO and polyamines could be useful as a combined treatment approach with hyperthermia $\left(42^{\circ} \mathrm{C}\right)$ or with other drugs, such as lysosomotropic compounds (Agostinelli and Seiler 2007), in the treatment of solid tumors, including melanomas and carcinomas, particularly those with MDR phenotypes, in earlier and later stages of disease.

Acknowledgments This work was partially supported by the Italian MIUR (Ministero dell'Istruzione, dell'Università e della Ricerca) and by funds MIUR-PRIN (Cofin). Thanks to 'Fondazione Sovena' for the scholarship given to Nikenza Viceconte for supporting her Ph.D.

\section{References}

Abell CW, Kwan SW (2001) Molecular characterization of monoamine oxidases A and B. Prog Nucleic Acid Res Mol Biol 65:129-156

Agostinelli E, Seiler N (2006) Non-irradiation-derived reactive oxygen species (ROS) and cancer: therapeutic implications. Amino Acids 31:341-355

Agostinelli E, Seiler N (2007) Lysosomotropic compounds and spermine enzymatic oxidation products in cancer therapy (review). Int J Oncol 31:473-484

Agostinelli E, Riccio P, Mucigrosso J, Befani O, Mondovì B (1988) On the handling of amine oxidase activity as a biochemical tool: perspectives. In: Perin A, Scalabrino G, Sessa A, Ferioli ME (eds) Perspectives in polyamine research. Wichtig Editor, Milan, pp 17-19

Agostinelli E, Morpurgo L, Wang C, Giartosio A, Mondovì B (1994a) Properties of cobalt-substituted bovine serum amine oxidase. Eur J Biochem 222:727-732

Agostinelli E, Przybytkowski E, Mondovì B, Averill-Bates DA (1994b) Heat enhancement of cytotoxicity induced by oxidation product of spermine in Chinese hamster ovary cells. Biochem Pharmacol 48:1181-1186

Agostinelli E, Arancia G, Calcabrini A, Matarrese P, Mondovì B, Pietrangeli $\mathrm{P}$ (1995) Hyperthermia-induced biochemical and ultrastructural modifications in cultured cells. Exp Oncol 17:269-276

Agostinelli E, Przybytkowski E, Averill-Bates DA (1996) Glucose, glutathione, and cellular response to spermine oxidation products. Free Rad Biol Med 20:649-656

Agostinelli E, De Mattheis G, Sinibaldi A, Mondovì B, Morpurgo L (1997) Reactions of the oxidized organic cofactor in copperdepleted bovine serum amine oxidase. Biochem J 324:497-501

Agostinelli E, Arancia G, Dalla Vedova L, Belli F, Marra M, Salvi M, Toninello A (2004) The biological functions of polyamine oxidation products by amine oxidases: perspectives of clinical applications. Amino Acids 27:347-358

Agostinelli E, Belli F, Dalla Vedova L, Longu S, Mura A, Floris G (2005) Catalytic properties and role of copper in bovine and lentil seedling copper/quinone-containing amine oxidases: controversial opinions. Eur J Inorg Chem 9:1635-1641

Agostinelli E, Belli F, Molinari A, Condello M, Palmigiani P, Dalla Vedova L, Marra M, Seiler N, Arancia G (2006a) Toxicity of enzymatic oxidation products of spermine to human melanoma cells (M14): sensitisation by heat and MDL 72527. Biochim Biophys Acta 1763:1040-1050

Agostinelli E, Belli F, Dalla Vedova L, Marra M, Crateri P, Arancia G (2006b) Hyperthermia enhances cytotoxicity of amine oxidase and spermine on drug-resistant LoVo colon adenocarcinoma cells. Int J Oncol 28:1543-1553

Agostinelli E, Dalla Vedova L, Belli F, Condello M, Arancia G, Seiler N (2006c) Sensitization of human colon adenocarcinoma cells (LoVo) to reactive oxygen species by a lysosomotropic compound. Int J Oncol 29:947-955

Agostinelli E, Tempera G, Molinari A, Salvi M, Battaglia V, Toninello A, Arancia G (2007a) The physiological role of biogenic amines redox reactions in mitochondria. New perspective in cancer therapy. Amino Acids 33:175-187

Agostinelli E, Tempera G, Dalla Vedova L, Condello M, Arancia G (2007b) MDL 72527 and spermine oxidation products induce a lysosomotropic effect and mitochondrial alterations in tumour effect. Biochem Soc Trans 35:343-348

Agostinelli E, Tempera G, Tandurella E, Pintus F, Spanò D, Medda $R$, Floris G (2009a) The role of copper amine oxidases in the metabolism of polyamine and their therapeutic implications. In: Dandrifosse G (ed) Biological aspects of biogenic amines, polyamines and conjugates, ISBN: 978-81-7895-249-9, Transworld Research Network, pp 33-49

Agostinelli E, Condello M, Molinari A, Tempera G, Viceconte N, Arancia G (2009b) Cytotoxicity of spermine oxidation products to multidrug resistant melanoma M14 ADR2 cells: sensitization by MDL 72527 lysosomotropic compound. Int J Oncol 35:485-498

Airenne TT, Nymalm Y, Kidron H, Smith DJ, Pihlavisto M, Salmi M, Jalkanen S, Johnson MS, Salminen TA (2005) Crystal structure of the human vascular adhesion structural features with functional implications. Protein Sci 14:1964-1974

Alarcon RA (1970) Acrolein IV. Evidence for the formation of the cytotoxic aldehyde acrolein from enzymatically oxidized spermine or spermidine. Arch Biochem Biophys 137:365-372

Andreyev A, Fiskum G (1999) Calcium induced release of mitochondrial cytochrome $c$ by different mechanisms selective for brain versus liver. Cell Death Differ 6:825-832

Arancia G, Calcabrini A, Meschini S, Molinari A (1998) Intracellular distribution of anthracyclines in drug resistant cells. Cytotechnology 27:95-111

Arancia G, Calcabrini A, Marra M, Crateri P, Artico M, Martone A, Martelli F, Agostinelli E (2004) Mitochondrial alterations induced by serum amine oxidase and spermine on human multidrug resistant tumor cells. Amino Acids 26:273-282

Atsawasuwan P, Mochida Y, Katafuchi M, Kaku M, Fong KSK, Csiszar K, Yamauchi M (2008) Lysyl oxidase binds transforming growth factor- $\beta$ and regulates its signaling via amine oxidase activity. J Biol Chem 283:34229-34240

Averill-Bates DA, Agostinelli E, Przybytkowski E, Mateescu MA, Mondovì B (1993) Cytotoxicity and kinetic analysis of purified bovine serum amine oxidase in the presence of spermine in Chinese hamster ovary cells. Arch Biochem Biophys 300:75-79

Averill-Bates DA, Cherif A, Agostinelli E, Tanel A, Fortier G (2005) Anti-tumoral effect of native and immobilized bovine serum amine oxidase in a mouse melanoma model. Biochem Pharmacol 69:1693-1704 
Averill-Bates DA, Ke Q, Tanel A, Roy J, Fortier G, Agostinelli E (2008) Mechanism of cell death induced by spermine and amine oxidase in mouse melanoma cells. Int J Oncol 32:79-88

Babbar N, Casero RA Jr (2006) Tumor necrosis factor $\alpha$ increases reactive oxygen species by inducing spermine oxidase in human lung epithelial cells: a potential mechanism for inflammation induced carcinogenesis. Cancer Res 66:11125-11130

Bachrach U, Ash I, Abu-Elheiga L, Hershkovitz M, Loyter A (1987) Fusion-mediated microinjection of active amine and diamine oxidases into cultured cells: effect on protein and DNA synthesis in chick embryo fibroblasts and in glioma cells. J Cell Physiol 131:92-98

Bachrach U, Wang YC, Tabib A (2001) Polyamines: new cues in cellular signal transduction. News Physiol Sci 16:106-109

Bates DA, Mackillop WJ (1990) The effect of hyperthermia in combination with melphalan on drug-sensitive and drug-resistant CHO cells in vitro. Br J Cancer 62:183-188

Bellelli A, Morpurgo L, Mondovi' B, Agostinelli E (2000) On the oxidation and reduction reactions of bovine serum amine oxidase: a kinetic study. Eur J Biochem 267:3264-3269

Ben-Hur E, Prager A, Riklis E (1978) Enhancement of thermal killing by polyamines. Survival of Chinese hamster cells. Int J Cancer 22:602-606

Bey P, Bolkenius FN, Seiler N, Casara P (1985) N-2,3-Butadienyl1,4-butanediamine derivatives: potent irreversible inactivators of mammalian polyamine oxidase. J Med Chem 28:1-2

Bianchi P, Kunduzova O, Masini E, Cambon C, Bani D, Raimondi L, Seguelas MH, Nistri S, Colucci W, Leducq N, Parini A (2005) Oxidative stress by mono amine oxidase mediates receptorindependent cardiomyocite apoptosis by serotonin and postischemic myocardial injury. Circulation 112:3297-3305

Binda C, Mattevi A, Edmondson DL (2002) Structure-function relationships in flavoenzyme-dependent amine oxidations. J Biol Chem 277:23973-23976

Binda C, Wang J, Pisani L, Caccia C, Carotti A, Salvati P, Edmondson DL, Mattevi A (2007) Structures of human monoamine oxidase B complexes with selective non covalent inhibitors: safinamide and coumarin analogs. J Med Chem 50:5848-5852

Boor P, Unzeta M, Salmi M, Jalkanen S (2009) Copper amine oxidases in adhesion molecules in renal pathology and in Alzheimer's disease and VAP-1 in leukocyte migration. In: Floris G, Mondovì B (eds) Copper amine oxidases. CRC press, Boca Raton, pp 195-217

Calcabrini A, Arancia G, Marra M, Crateri P, Befani O, Martone A, Agostinelli E (2002) Enzymatic oxidation products of spermine induce greater cytotoxic effects on human multidrug- resistant colon carcinoma cells (LoVo) than on their wild type counterparts. Int J Cancer 99:43-52

Calderone V, Di Paolo ML, Trabucco M, Biadene M, Battistutta R, Rigo A, Zanotti G (2003) Crystallization and preliminary X-ray data of amine oxidase from bovine serum. Acta Crystallogr D Biol Crystallogr 59:727-729

Casero RA Jr, Marton LJ (2007) Targeting polyamine metabolism and function in cancer and other hyperproliferative diseases. Nat Rev Drug Discov 6:373-390

Casero RA Jr, Pegg A (2009) Polyamine catabolism and disease. Biochem J 421:323-338

Checkoway H, Franklin GM, Costa-Mallen P, Smith-Weller T, Dilley J, Swansons PD, Costa LG (1998) A genetic polymorphism of MAO-B modifies the association of cigarette smoking and Parkinson's disease. Neurology 50:1458-1461

Childs AC, Mehta DJ, Gerner EW (2003) Polyamine-dependent gene expression. Cell Mol Life Sci 60:1394-1406

Cohen SS (ed) (1998) A guide to the polyamines. Oxford University Press, New York
Dai H, Kramer DL, Yanag C, Murti KG, Porter CW, Cleveland JL (1999) The polyamine oxidase inhibitor MDL 72527 selectively induces apoptosis of transformed haematopoietic cells through lysosomotropic effects. Cancer Res 59:4944-4955

De Biase D, Agostinelli E, De Matteis G, Mondovì B, Morpurgo L (1996) Half-of-the-sites reactivity of bovine serum amine oxidase. Reactivity and chemical identity of the second site. Eur J Biochem 237:93-99

Demers N, Agostinelli E, Averill-Bates DA, Fortier G (2001) Immobilization of native and polyethyleneglycol-treated ("PEGylated") bovine serum amine oxidase into a biocompatible hydrogel. Biotechnol Appl Biochem 33:201-207

Dini L, Agostinelli E, Mondovi B (1991) Cultured hepatocytes bind and internalize bovine serum amine oxidase-gold complex. Biochem Biophys Res Commun 179:1169-1174

Duff AP, Cohen AE, Ellis PJ, Kuchar JA, Langley DB, Shepard EM, Dooley DM, Freeman HC, Guss JM (2003) The crystal structure of Pichia pastoris lysyl oxidase. Biochemistry 42:15148-15157

Edmondson DL, Binda C, Mattevi A (2007) Structural insights into the mechanism of amine oxidation by monoamine oxidase $\mathrm{A}$ and B. Arch Biochem Biophys 464:269-276

Edmondson DL, Binda C, Wang J, Upadhyay AK, Mattevi A (2009) Molecular and mechanistic properties of the membrane-bound mitochondrial monoamine oxidases. Biochemistry 48:4220 4230

Floris G, Mondovì B (2009) Copper amine oxidases. CRC Press, Boca Ranton

Gahl WA, Pitot HC (1982a) Polyamine degradation in foetal and adult bovine serum. Biochem J 202:603-611

Gahl WA, Vale AM, Pitot HC (1982b) Spermidine oxidase in human pregnancy serum. Biochem J 201:161-166

Gerner EW, Meyskens FL Jr (2009) Combination chemoprevention for colon cancer targeting polyamine synthesis and inflammation. Clin Cancer Res 15:758-761

Gerner EW, Holmes DK, Stickney DG, Noterman JA, Fuller DJ (1980) Enhancement of hyperthermia induced cytotoxicity by polyamines. Cancer Res 40:432-438

Gerner EW, Meyskens FL Jr, Goldschmid S, Lance P, Pelot D (2007) Rationale for, and design of, a clinical trial targeting polyamine metabolism for colon cancer chemoprevention. Amino Acids 33:189-195

Gervasoni JE Jr, Fields SZ, Krishna S, Baker MA, Rosado M, Thuraisamy K, Hinderburg AA, Taub RN (1991) Subcellular distribution of doxorubicin in P-glycoprotein-positive and negative drug resistant cell lines using laser-assisted confocal microscopy. Cancer Res 51:4955-4963

Ghafourifar P, Klein SD, Schucht O, Schenk U, Pruschy M, Rocha S, Richter C (1999) Ceramide induces cytochrome c release from isolated mitochondria. Importance of mitochondrial redox state. J Biol Chem 274:6080-6084

Gottesman MM, Pastan I (1993) Biochemistry of multidrug resistance mediated by the multidrug transporter. Annu Rev Biochem 62:385-427

Green EL, Nakamura N, Dooley DM, Klinman JP, Sanders-Loehr J (2002) Rates of oxygen and hydrogen exchange as indicators of TPQ cofactor orientation in amine oxidases. Biochemistry 41:687-696

Guicciardi ME, Leist M, Gores GJ (2004) Lysosomes in cell death. Oncogene 23:2881-2890

Hahn GM (1982) Plenum Press, New York

Hartmann C, Klinman JP (1991) Structure-function studies of substrate oxidation by bovine serum amine oxidase: relationship to cofactor structure and mechanism. Biochemistry 30:46054611

Heby O, Persson L (1990) Molecular genetics of polyamine synthesis in eukaryotic cells. Trends Biochem Sci 15:153-158 
Hengartner MO (2000) The biochemistry of apoptosis. Nature 407:770-776

Henle KJ, Moss AJ, Nagle WA (1986) Mechanism of spermidine cytotoxicity at 37 degrees $\mathrm{C}$ and 43 degrees $\mathrm{C}$ in Chinese hamster ovary cells. Cancer Res 46:175-182

Houen G (1999) Mammalian Cu-containing amine oxidases (CAOs). New methods of analysis, structural relationships, and possible functions. Acta Pathol Microbiol Immunol Scand 107:5-46

Israel M, Zoll EC, Muhammad N, Modest EJ (1973) Synthesis and antitumor evaluation of the presumed cytotoxic metabolites of spermine and $N, N$-bis (3-aminopropyl)nonane-1,9-diamine. J Med Chem 16:1-5

Issels R (1999) Hyperthermia combined with chemotherapybiological rationale, clinical application, and treatment results. Onkologie 22:374-381

Janes SM, Klinman JP (1991) An investigation of bovine serum amine oxidase active site stoichiometry: evidence for an aminotransferase mechanism involving two carbonyl cofactors per enzyme dimer. Biochemistry 30:4599-4605

Janes SM, Mu D, Wemmer D, Smith AJ, Kaur S, Maltby D, Burlingame AL, Klinman JP (1990) A new redox cofactor in eukaryotic enzymes: 6-hydroxydopa at the active site of bovine serum amine oxidase. Science 248:981-987

Kumar V, Dooley DM, Freeman HC, Guss JM, Harvej J, McGuirl MA, Wilce MC, Zubak V (1996) Crystal structure of the eukaryotic (pea seedling) copper-containing amine oxidase at $2.2 \AA$ resolution. Structure 4:943-955

La Regina G, Silvestri R, Artico M, Lavecchia A, Novellino E, Befani O, Turini P, Agostinelli E (2007) New pyrrole inhibitors of monoamine oxidase: synthesis, biological evaluation, and structural determinants of MAO-A and MAO-B selectivity. J Med Chem 50:922-931

Lee Y, Sayre LM (1998) Reaffirmation that metabolism of polyamines by bovine plasma amine oxidase occurs strictly at the primary amino termini. J Biol Chem 273:19490-19494

Li R, Klinman JP, Mathews FS (1998) Copper amine oxidase from Hansenula polymorpha: the crystal structure determined at $2.4 \mathrm{~A}$ resolution reveals the active conformation. Structure 6:293-307

Lindsay GS, Wallace HM (1999) Changes in polyamine catabolism in HL-60 human promyelogenous leukaemic cells in response to etoposide-induced apoptosis. Biochem J 337:83-87

Lord-Fontaine S, Agostinelli E, Przybytkowski E, Averill-Bates DA (2001) Amine oxidase, spermine, and hyperthermia induce cytotoxicity in P-glycoprotein overexpressing multidrug resistant Chinese hamster ovary cells. Biochem Cell Biol 79:165-175

Lucero HA, Ravid K, Grimsby JL, Rich CB, DiCamillo SJ, Maki JM, Myllyharju J, Kagan HM (2008) Lysyl oxidase oxidizes cell membrane proteins and enhances the chemotactic response of vascular smooth muscle cells. J Biol Chem 283:24103-24117

Lunelli M, Di Paolo ML, Biadene M, Calderone V, Battistutta R, Scarpa M, Rigo A, Zanotti G (2005) Crystal structure of amine oxidase from bovine serum. J Mol Biol 346:991-1004

Lyles GA (1996) Mammalian plasma and tissue-bound semicarbazide-sensitive amine oxidases: biochemical, pharmacological and toxicological aspects. Int J Biochem Cell Biol 28:259-274

Mallajosyula JK, Kaur D, Chinta SJ, Rajagopalan S, Rane A, Nicholls DG, Di Monte DA, Macarthur H, Andersen JK (2008) MAO B elevation in mouse brain astrocytes results in Parkinson's pathology. PlosOne 3:e-1616

Malorni W, Giammarioli AM, Matarrese P, Pietrangeli P, Agostinelli E, Ciaccio A, Grassilli E, Mondovì B (1998) Protection against apoptosis by monoamine oxidase A inhibitors. FEBS Lett 426:155-159

Marti L, Abella A, De La Cruz X, Garcìa-Vicente S, Unzeta M, Carpènè C, Palacìn M, Testar X, Orozco M, Zorzano A (2004) Exploring the binding mode of semicarbazide-sensitive amine
oxidase/VAP-1: identification of novel substrates with insulinlike activity. J Med Chem 47:4865-4874

Mc Laren CE, Fujikawa-Brooks S, Chen WP, Gilen DL, Pelot D, Gerner EW, Meyskens FL Jr (2008) Longitudinal assessment of air conduction audiograms in a phase III clinical trials of difluoromethylornithine and sulindac for prevention of sporadic colorectal adenomas. Cancer Prev Res (Phila Pa) 1:499-502

Mitchell Guss J, Zanotti G, Salminen TA (2009) Copper amine oxidases crystal structures. In: Floris G, Mondovì B (eds) Copper amine oxidases. CRC press, Boca Raton, pp 119-142

Mondovì B, Riccio P, Agostinelli E, Marcozzi G (1989) Oxidation of diamines and polyamines. In: Bachrach U, Heimer YM (eds) The physiology of polyamines, vol 1. CRC Press, Boca Raton, pp 177-201

Morgan DML (1988) Polyamine oxidases and oxidized polyamines. In: Bachrach U, Heimer Y (eds) The physiology of polyamines, vol 1. CRC Press, Boca Raton, pp 203-229

Morpurgo L, Agostinelli E, Mondovì B, Avigliano L, Silvestri R, Stefancich G, Artico M (1992) Bovine serum amine oxidase: half-site reactivity with phenylhydrazine, semicarbazide, and aromatic hydrazides. Biochemistry 31:2615-2621

Mu D, Janes SM, Smith AJ, Brown DE, Dooley DM, Klinman JP (1992) Tyrosine codon corresponds to topaquinone at the active site of copper amine oxidases. J Biol Chem 267:7979-7982

Nagele A, Meier T, Issels RD (1990) Thermosensitization, depletion of glutathione, and modulation of polyamine catabolism in $\mathrm{CHO}$ cells by the aminothiol WR-1065. Prog Pharm Clin Pharm $8: 176-180$

Nakamura N, Möenne-Loccoz P, Tanizawa K, Mure M, Suzuki S, Klinman JP, Sanders-Loehr J (1997) Topaquinone-dependent amine oxidases: identification of reaction intermediates by Raman spectroscopy. Biochemistry 36:11479-11486

Nayvelt I, Thomas T, Thomas TJ (2007) Mechanistic differences in DNA nanoparticle formation in the presence of oligolysines and poly-L-lysine. Biomacromolecules 8:477-484

Nymalm Y, Kidron H, Söderholm A, Viitanen L, Kaukonen K, Pihlavisto M, Smith D, Veromaa T, Airenne TT, Johnson MS, Salminen TA (2003) Crystallization and preliminary X-ray analysis of the human vascular adhesion protein-1. Acta Crystallogr D Biol Crystallogr 59:1288-1290

O’Sullivan J, Unzeta M, Healy J, O'Sullivan MI, Davey G, Tipton KF (2004) Semicarbazide-sensitive amine oxidases: enzymes with quite a lot to do. NeuroToxicology 25:303-315

Parsons MR, Convery MA, Wilmore CM, Yadav KD, Blakeley V, Corner AS, Phillips SE, McPherson MJ, Knowles PF (1995) Crystal structure of a quinonenzyme copper amine oxidase of Escherichia coli at $2 \AA$ resolution. Structure 3:1171-1184

Paterson LA, Tatton WG (1998) Antiapoptotic actions of monoamine oxidase B inhibitors. Adv Pharmacol 42:312-315

Pegg AE (1988) Polyamine metabolism and its importance in neoplastic growth and a target for chemotherapy. Cancer Res 48:759-774

Salmi M, Jalkanen S (2006) Development regulation of the adhesive and enzymatic activity of vascular adhesion protein (VAP-1) in humans. Blood 108:1555-1561

Salminen TA, Smith DJ, Jalkanen S, Johnson MS (1998) Structural model of the catalytic domain of an enzyme with cell adhesion activity: human vascular adhesion protein-1 (HVAP-1) D4 domain is an amine oxidase. Protein Eng 11:1195-1204

Seiler N (1992) Polyamine catabolism and elimination by the vertebrate organism. In: Dowling RH, Fölsch UR, Löser G (eds) Polyamines in the gastrointestinal tract. Kluwer Academic Publishers, Dordrecht, pp 65-85

Seiler N (1994) Formation, catabolism and properties of the natural polyamines. In: Carter C (ed) The neuropharmacology of polyamines. Academic Press, London, pp 1-36 
Seiler N (2000) Oxidation of polyamines and brain injury. Neurochem Res 25:471-490

Seiler N (2004) Catabolism of polyamines. Amino Acids 26:217-233

Seiler N, Raul F (2005) Polyamines and apoptosis. J Cell Mol Med 9:623-642

Seiler N, Duranton B, Raul F (2002) The polyamine oxidase inactivator MDL 72527. Prog Drug Res 59:1-40

Sharmin S, Sakata K, Kashiwagi K, Ueda S, Iwasaki S, Shirahata A, Igarashi K (2001) Polyamine cytotoxicity in the presence of bovine serum amine oxidase. Biochem Biophys Res Commun 282:228-235

Simoneau AR, Gerner EW, Nagle R, Ziogas A, Fujikawa-Brooks S, Yerushalmi H, Ahlering TE, Lieberman R, McLaren CE, AntonCulver H, Meyskens FL Jr (2008) The effect of difluoromethylornithine on decreasing prostate size and polyamines in men: results of a year-long phase II b randomized placebo-controlled chemoprevention trial. Cancer Epidemiol Biomarkers Prev 17:292-299

Stefanelli C, Bonavita F, Stanic' I, Mignani M, Facchini A, Pignatti C, Flamigni F, Caldarera CM (1998) Spermine causes caspase activation in leukaemia cells. FEBS Lett 437:233-236

Stefanelli C, Bonavita F, Stanic' I, Pignatti C, Flamigni F, Guarnieri C, Caldarera CM (1999) Spermine triggers the activation of caspase-3 in a cell-free model of apoptosis. FEBS Lett 451:9598

Stefanelli C, Stanic' I, Zini M, Bonavita F, Flamigni F, Zambonin L, Landi L, Pignatti C, Guarnieri C, Caldarera CM (2000) Polyamines directly induce release of cytochrome $c$ from heart mitochondria. J Biochem 347:875-880

Stolen CM, Yegutkin GG, Kurkijarvi R, Bono P, Alitalo K, Jalkanen $S$ (2004) Origins of serum semicarbazide-sensitive amine oxidase. Circ Res 95:50-57

Strolin Benedetti M, Tipton KF, Whomsley R, Baltes E (2007) Factors affecting the relative importance of amine oxidases and monooxygenases in the in vivo metabolism of xenobiotic amines in humans. J Neural Transm 114:787-791

Su Q, Klinman JP (1998) Probing the mechanism of proton coupled electron transfer to dioxygen: the oxidative half-reaction of bovine serum amine oxidase. Biochemistry 37:12513-12525

Tabor CW, Tabor H (1984) Polyamines. Annu Rev Biochem 53:749790

Tabor H, Tabor CW, Bachrach U (1964) Identification of the amino aldehydes produced by the oxidation of spermine and spermidine in purified plasma amine oxidase. J Biol Chem 239:2194-2203
Tipton KF, O’Sullivan MI, Davey GP, O’Sullivan JO (2003) It can be a complicated life being an enzyme. Biochem Soc Trans 31:711715

Tipton KF, Boyce S, O'Sullivan J, Davey GP, Healy J (2004) Monoamine oxidases: certainties and uncertainties. Curr Med Chem 11:1965-1982

Tobias KE, Kahana C (1995) Exposure to ornithine results in excessive accumulation of putrescine and apoptotic cell death in ornithine decarboxylase overproducing mouse myeloma cells. Cell Growth Differ 6:1279-1285

Toninello A, Salvi M, Mondovì B (2004) Interaction of biologically active amines with mitochondria and their role in the mitochondrial-mediated pathway of apoptosis. Curr Med Chem 11:23492374

Turini P, Sabatini S, Befani O, Chimenti F, Casanova C, Riccio P, Mondovì B (1982) Purification of bovine plasma amine oxidase. Anal Biochem 125:294-298

Urano M, Kuroda M, Nishimura Y (1999) For the clinical application of thermochemotherapy given at mild temperatures. Int J Hyperthermia 15:79-107

Vujcic S, Diegelman P, Bacchi CJ, Kramer DL, Porter CW (2002) Identification and characterization of a novel flavin containing spermine oxidase of mammalian cell origin. Biochem J 367:665675

Wallace HM, Fraser AV (2003) Polyamines analogues as anticancer drugs. Biochem Soc Trans 31:393-396

Wallace HM, Niiranen K (2007) Polyamine analogues-an update. AminoAcids 33:261-265

Wang Y, Devereux W, Woster PM, Stewart TM, Hacker A, Casero RA Jr (2001) Cloning and characterization of human polyamine oxidase that is inducible by polyamine analogue exposure. Cancer Res 61:5370-5373

Wilce MCJ, Dooley DM, Freeman HC, Guss JM, Matsunami H, McIntire WS, Ruggiero CE, Tanizawa K, Yamaguchi H (1997) Crystal structures of the copper-containing amine oxidase from Arthrobacter globiformis in the holo and apo forms: implications for the biogenesis of topaquinone. Biochemistry 36:16116-16133

Yegutkin GG, Salminen T, Koskinen K, Kurtis C, McPherson MJ, Jalkanen S, Salmi M (2004) A peptide inhibitor of vascular adhesion protein-1 (VAP-1) blocks leukocyte-endothelium interactions under shear stress. Eur J Immunol 34:2276-2285

Yu PH, Wright S, Fan EH, Lun ZR, Gubisne-Harberle D (2003) Physiological and pathological implications of semicarbazidesensitive amine oxidase. Biochim Biophys Acta 1647:193-199 